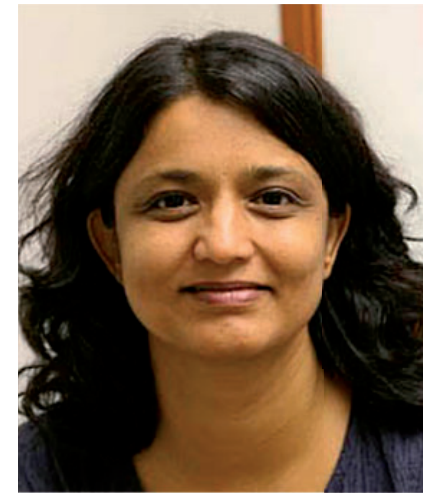

Manu Goswami

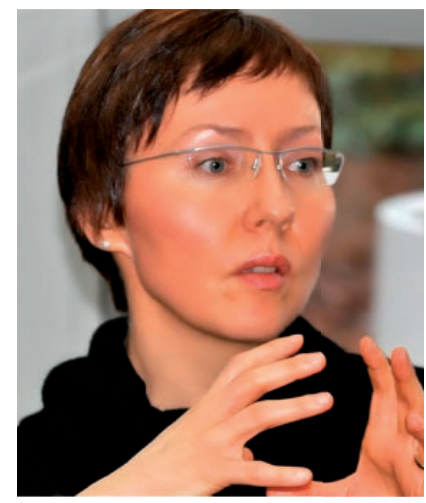

Anna Krylova

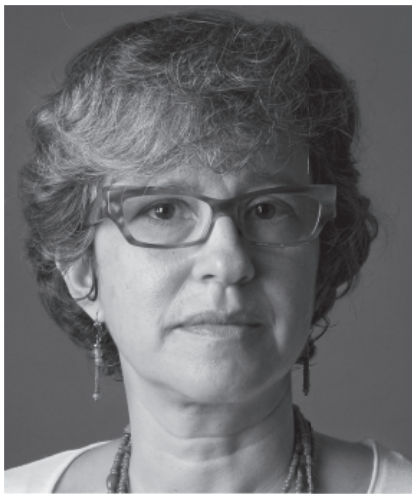

Gabrielle Hecht

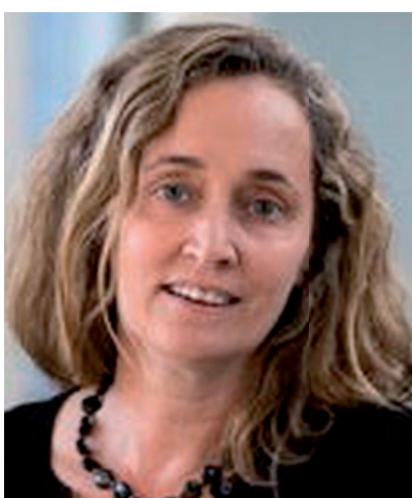

Elizabeth F. Thompson

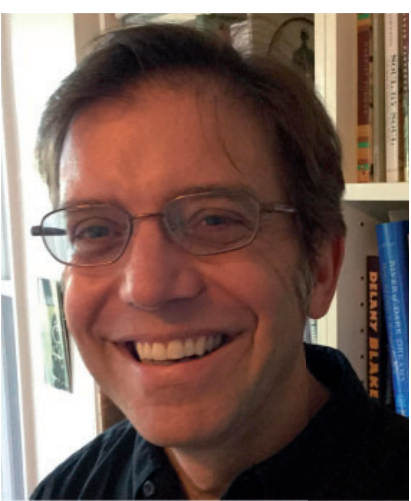

Andrew Zimmerman

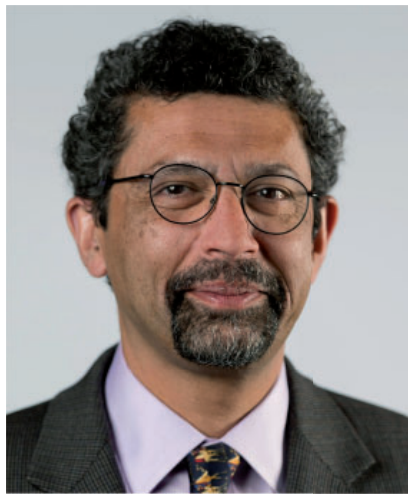

Adeeb Khalid

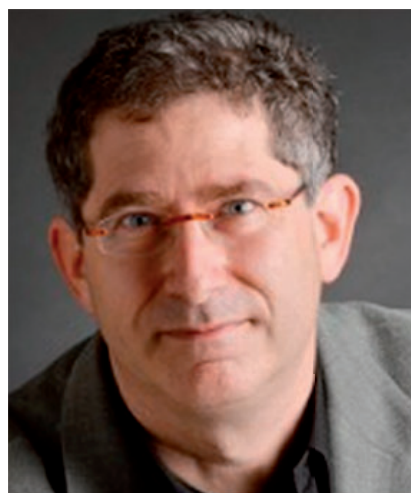

Jonathan R. Zatlin 


\title{
AHR Conversation History after the End of History: Reconceptualizing the Twentieth Century
}

\section{PARTICIPANTS:}

\author{
Manu Goswami, Gabrielle Hecht, Adeeb Khalid, \\ Anna Krylova, Elizabeth F. Thompson, Jonathan R. Zatlin, \\ AND ANDREW ZiMMERMAN
}

Over the last decade, this journal has published eight $A H R$ Conversations on a wide range of topics. By now, there is a regular format: the Editor convenes a group of scholars with an interest in the topic who, via e-mail over the course of several months, conduct a conversation that is then lightly edited and footnoted, finally appearing in the December issue. The goal has been to provide readers with a wide-ranging and accessible consideration of a topic at a high level of expertise, in which participants are recruited across several fields. It is the sort of publishing project that this journal is uniquely positioned to take.

The initial impulse for the 2016 conversation came from a Mellon Sawyer Seminar on "Reinterpreting the Twentieth Century," held at Boston University in 2014-2015. That seminar, convened by Andrew Bacevich, Brooke Bower, Bruce Schulman, and Jonathan Zatlin, invited participants to "challenge our assumptions about the twentieth century, its ideologies, debates, divides, and more," in a broad-based effort to "create new chronologies and narratives that engage with our current hopes and struggles." ${ }^{1}$ For the $A H R$, this is a departure from previous Conversation topics, in that it is chronologically bounded rather than thematically defined. That said, the Editor made a concerted effort to assemble a group of scholars working in myriad subfields and drawing on a diverse range of "area studies" paradigms (though no doubt many of them would reject that very concept). The result, while inevitably leaving some very important regions out of the discussion (China comes to mind!), proved enriching and thought-provoking and should be of interest to readers interested in historical questions far beyond particular regional specializations or even the twentieth century itself.

1 "Reinterpreting the Twentieth Century: A Mellon Sawyer Seminar Series," Boston University Department of History, http://www.bu.edu/history/news-events/conferences/sawyer/.

(C) The Author(s) 2016. Published by Oxford University Press on behalf of the American Historical Association. All rights reserved. For permissions, please e-mail journals.permissions@oup.com. 
The Conversation was led by the 2015-2016 Interim Editor, Alex Lichtenstein. Joining him are Manu Goswami, a historian of South Asia from New York University; Gabrielle Hecht, a specialist in the history of technology and African history at the University of Michigan; Adeeb Khalid, a scholar of modern Central Asian history from Carleton College; Anna Krylova, a historian of modern Russia at Duke University who is also interested in questions of theory and methodology of historical writing; Elizabeth F. Thompson, a historian of the Middle East at American University; Jonathan Zatlin, a scholar of modern Germany at Boston University and one of the conveners of the original Sawyer Seminar at BU; and Andrew Zimmerman from George Washington University, a scholar of nineteenth-century transnational and comparative history with a strong theoretical bent. Lichtenstein opened the Conversation by asking participants to respond directly to Charles Maier's millennial assessment, "Consigning the Twentieth Century to History," published in the $A H R$ in June $2000 .^{2}$ In that essay, Maier deployed some key concepts that he believed could help historians organize their understanding of the century just past: "moral narratives," "structural narratives" (the two often out of sync), and, especially, "territoriality." From there, a very broad discussion ensued, touching on multiple forms of political power, questions of human agency, notions of subjectivity, and the competing narrative forms that we imagine allow us to make sense of the recent past-and thus our present. On this latter point, many of the participants throw into doubt the linear narratives of historical progress that so many theories of diachronic change seem to share.

The Conversation will continue with members of the audience at a panel at the AHA Annual Meeting in Denver in January 2017, with Krylova, Lichtenstein, and Zatlin as participants. We invite all those who read this and have remarks of their own to join us there.

AHR Editor (Alex Lichtenstein): The topic of this year's Conversation is somewhat unusual, in that it focuses on an epoch rather than a trans-temporal theme. Nevertheless, my hope is that all historians, whatever their interests, will be drawn to a discussion of how we might understand the most recent century. If nothing else, this forces us to reckon with how human beings attempt to create narrative coherence from a past that remains in living memory. How do we imagine and mark an epoch at its fading? How does each successive generation of historians craft a temporal framework out of their own past, and that of their parents and grandparents? What kinds of methodologies can historians in different fields bring to bear on defining an epoch? Which events and developments stand out, and why? How might this differ according to the particular regional or topical expertise a historian brings to the table? Surely, for example, the twentieth century looks dramatically different from either side of the Berlin Wall, or across the North-South divide. Moreover, a historian of gender, a Marxist scholar, or a historian of technology (not that these are mutually exclusive categories) may see things quite distinctively. As Charles Maier asked in the pages of the $A H R$ in 2000, "Will the twentieth century cohere as a historical epoch?"3

${ }^{2}$ Charles S. Maier, "Consigning the Twentieth Century to History: Alternative Narratives for the Modern Era," American Historical Review 105, no. 3 (June 2000): 807-831.

${ }^{3}$ Ibid., 807. 
With these questions in mind, I would like to invite each of you to begin by addressing from your own particular field's perspective what kind of "moral narratives" and "structural narratives" - to rely on the terms Maier favored in his 2000 essay-might be available as we assess the twentieth century. Maier, for his part, aimed at "periodizing modern history" around the concept of "territoriality."4 Is this sufficient?

Gabrielle Hecht: I'm still working out whether I agree with the thrust of Maier's essay: namely, that territoriality can serve as a primary periodization tool, defining a historical epoch that begins around 1860 and ends in the 1970s. But his analysis is certainly good to think with.

Taking the history of technology as a starting point, Maier's case for beginning a new period around 1860 is compelling. Infrastructural technologies such as railroads and telegraphs laid down corridors of power in metropoles and empires, facilitating conquest, extending landscapes, and enabling at least some measure of administration (often quite a large measure). We could think about this as an upscaling of capacity, a fundamental shift in elite technopolitical power that shaped states and corporations. Historians have spent a great deal of energy unpacking the progress ideologies that accompanied such infrastructural extensions. ${ }^{5}$ Doing so inevitably produces moral narratives. Most obviously, the twentieth century (however defined) saw a massive increase in the capacity to kill: tools of colonial conquest, such as machine guns and aerial bombing, spread to other battlefields; industrialized slaughter accounted for the terrifying efficiency of the Holocaust; atomic bombs made apocalyptic imaginaries materially plausible. ${ }^{6}$

Yet can such moral narratives be clearly distinguished from structural ones? The more you dig, the harder it becomes to disentangle these two types of chronicles. Particularly when you juxtapose the immediate violence enacted (or conjured) by such developments with the "slow violence" of infrastructural expansion. ${ }^{7}$ As we begin this conversation, lead contamination in Flint, Michigan (some fifty miles north of where I sit), is hitting the U.S. national media. This poisoning of Flint residents comes from the encounter between old pipes and untreated water. It also comes from a long series of decisions and non-decisions having to do with deferred maintenance, as well as from the structural manifestations and intersections of poverty and race. ${ }^{8}$ Such technopolitical entanglements turn state and corporate apparatuses into toxic infrastructures, not just in Flint but around the world. These dynamics help us see why periodizing the recent past is so charged: the act of periodization itself can activate politics of accountability, adjudications of blame, claims for compensation, assertions of rights. (These politics of

${ }^{4}$ Ibid., 807-808.

${ }^{5}$ One example among many: Michael Adas, Machines as the Measure of Men: Science, Technology, and Ideologies of Western Dominance (Ithaca, N.Y., 1989).

${ }^{6}$ A particularly compelling rendition of this trend can be found in Sven Lindqvist, A History of Bombing (New York, 2001).

${ }^{7}$ Rob Nixon, Slow Violence and the Environmentalism of the Poor (Cambridge, Mass., 2013). There is a wide range of work on similar themes, including Michelle Murphy, Sick Building Syndrome and the Problem of Uncertainty: Environmental Politics, Technoscience, and Women Workers (Durham, N.C., 2006); Nancy Langston, Toxic Bodies: Hormone Disruptors and the Legacy of DES (New Haven, Conn., 2010); Brett L. Walker, Toxic Archipelago: A History of Industrial Disease in Japan (Seattle, Wash., 2010).

${ }^{8}$ This dynamic is illuminated by histories of risk and disaster management, such as Scott Gabriel Knowles, The Disaster Experts: Mastering Risk in Modern America (Philadelphia, 2011); and Arwen P. Mohun, Risk: Negotiating Safety in American Society (Baltimore, 2013). 
periodization emerge particularly clearly in debates around the Anthropocene, about which I'll probably say more later on in the conversation.)

With all this in mind, let me return briefly to territoriality. Might we deepen its analytic work by thinking about verticality? Territoriality, as deployed in Maier's essay, is primarily about two-dimensional extensions in space, whether land or maritime; he doesn't exclude the third dimension, but he doesn't focus on it, either. Pondering power "volumetrically" doesn't just take us to aerial or submarine warfare. Going up makes us consider skyscrapers, satellites, and outer space. Going down makes us contemplate cables, tunnels, and mines. Verticality matters to the forms of power enacted by such technopolitical assemblages. ${ }^{9}$ How can thinking in three dimensions shape our understanding of the twentieth century?

Andrew Zimmerman: I like how Maier both distinguished structural from moral narratives of the twentieth century and also posed the question of their articulation. He seemed to predict the decline of the moral narrative that yokes together the Holocaust and the Gulag as a warning against any large-scale, radical social change. That narrative, along with the concept of "totalitarianism" underlying it, was brilliantly skewered by Slavoj Žižek in his 2001 Did Somebody Say Totalitarianism? ${ }^{10}$ Maier's prediction of the decline of the totalitarian narrative was bold (and in my view optimistic) in 2000, at the end of the '90s, when the market-based (or "civil society") politics of neoliberalism still seemed hegemonic. Maier predicted the increasing relevance of more radical political narratives, based in the struggles against colonialism, other forms of global inequality, and associated forms of oppression existing in the Global North as well as the Global South. In a way, the recent Democratic primary contest between Hillary Clinton and Bernie Sanders revealed a heightened conflict between these two narratives, and reflected an at least partial delegitimization of the neoliberal narrative. The neoliberal anti-“totalitarian" moral narrative continues to flourish, but, as Maier predicted, the anticolonial narrative also grows stronger, and not just inside history departments. Maier worried that the decline of territoriality (the structural narrative he outlined) would make it difficult for the moral narrative of anticolonialism to become politically effective. The playing field, in my view, remains level, however, since the decline of territoriality has also weakened the politics of neoliberalism, whose dependence on territorial state power was perhaps less obvious fifteen years ago.

I like Gabrielle's suggestion to add a vertical dimension to the structural narrative of territorialization, especially as a way to think about environmental justice concerns, from Flint to global climate change. We could speak here of a new round of enclosures, as the rich seize the air, water, climate from the poor as dumping grounds for toxic waste and/or sources of accumulation by dispossession. Jason Moore has developed a powerful analytic for thinking about capitalism as an ecology that is relevant here. ${ }^{11}$ The question then becomes how this structural narrative, the three-dimensional narra-

${ }^{9}$ Stuart Elden, "Secure the Volume: Vertical Geopolitics and the Depth of Power," Political Geography 34 (May 2013): 35-51; Eyal Weizman, Hollow Land: Israel's Architecture of Occupation (London, 2012); Nicole Starosielski, The Undersea Network (Durham, N.C., 2015).

${ }_{10}$ Slavoj Žižek, Did Somebody Say Totalitarianism? Five Interventions in the (Mis)Use of a Notion (London, 2011).

${ }^{11}$ Jason W. Moore, Capitalism in the Web of Life: Ecology and the Accumulation of Capital (London, 2015). 
tive of slow violence and toxic infrastructures that Gabrielle highlights, articulates with the two moral narratives of the twentieth century that Maier identified: neoliberal anti"totalitarianism" and radical anti-imperialism (and critiques of associated inequalities of race, gender, and class). Neoliberals were the ones to proclaim an end of history in the 1990s, but in 2015 it seems to be the anti-imperialists who are concerned about the end of history, albeit in a far more dystopian sense than the neoliberals had been.

Manu Goswami: Published some sixteen years ago, Maier's essay serves as a strong riposte to frameworks that reduce historical temporality to chronology and those that treat historical periodization in formalistic terms as simply establishing and emending timelines. Like Gabrielle, however, I find the hard-and-fast binary between moral versus structural narratives too sharply drawn to sustain. I agree with Andrew that the essay boldly, if controversially, questions the conflation of regionally grounded normative reckonings centered on the catastrophes of the Holocaust and the Gulag with the global scale as such. This conflation arguably helped buoy an "anti-totalitarian" consensus narrative that saturated the post-'89 era, amid Cold War triumphalism and the spread of market-disciplinary neoliberal creeds. Here I want to raise two linked concerns about the substantive claims of Maier's essay-first, its view of territoriality as something amenable to a "rise and fall" metric, and second, its treatment of anti-imperialism as merely a moral narrative. ${ }^{12}$

Maier's conception of territoriality is overwhelmingly tied to a state-centered and state-directed understanding of infrastructures of power and institutional capacity. I was struck by how much this narrative-of the intensive territorialization of state power-synthesizes a specifically Weberian tradition of historical sociology. I am thinking here of Michael Mann's multiple-volume work on the sources of social power that developed an argument about the infrastructural powers of the modern state and Anthony Giddens's conception of the modern state as a "bordered power container."13 This is a powerful line of inquiry. Yet it also presupposed the nation-state as its default unit, bracketing both imperial state formations and the specifically imperial scale of capitalism across the long nineteenth century. Against the limits of this tradition, it might be useful to recall the work of the heterodox Marxian social philosopher Henri Lefebvre for its distinct treatment of the articulation of state, capital, and territoriality. Lefebvre's work on social space, elaborated amid the diverse political and economic cataclysms of the 1970s, sought to account for the survival of capitalism, for its astonishing persistence despite multifarious contradictions and accelerating social, ecological, and political costs. ${ }^{14}$ One of the answers that Lefebvre develops across The Production of Space and the multivolume work on state space centers on how capitalism, along with the state, relies upon the continual production and management of a diverse and

${ }^{12}$ Maier, "Consigning the Twentieth Century to History," 812.

${ }^{13}$ Charles Tilly, Coercion, Capital and European States, AD 990-1992, revised ed. (Cambridge, Mass., 1992); Michael Mann, The Sources of Social Power, vol. 2: The Rise of Classes and Nation-States, 1760-1914 (Cambridge, 1993); Anthony Giddens, A Contemporary Critique of Historical Materialism, vol. 2: The Nation-State and Violence (Cambridge, 1985), 120.

${ }^{14}$ Henri Lefebvre, The Production of Space, trans. Donald Nicholson-Smith (1974; repr., Oxford, 1991); Lefebvre, The Survival of Capitalism (London, 1976); Lefebvre, State, Space, World: Selected Essays, ed. Neil Brenner and Stuart Elden, trans. Gerald Moore, Neil Brenner, and Stuart Elden (Minneapolis, 2009). 
hierarchically ordered ensemble of spaces. Lefebvre's conception of capitalist spacetime as simultaneously global, hierarchical, and fragmented is pertinent precisely because of its emphasis on a multiform and contradictory order. Its focus on produced spaces rather than a pre-given or fixed realm of territoriality cannot be assimilated to a unilineal periodization - the "rise and fall" —of territoriality. From this vantage, the post-1970s era of state/capital relations entailed less the decomposition and dissolution of territoriality than a dynamic rescaling - a simultaneous reterritorialization and deterritorialization - of national state power, sectors of capital, and modes of collective subjectivity. The "end-of-territoriality" thesis that underwrites Maier's essay unwittingly reiterates the state-decline thesis and utopian projections of a borderless, friction-free world that have been key elements of neoliberal globalism. ${ }^{15}$ The absence of capitalism as an organizing category of analysis leads, I think, to an unduly flat and static conception of territoriality, one that glosses over such distinct political forms as empire and nation as well as internal caesuras within twentieth-century capitalism.

My point here is less to disagree with Maier's emphasis on a growing territorial alignment between governance and collective identity—what he terms "decision space" and "identity space" - across the temporal period of 1860 to $1970 .{ }^{16}$ Rather, in order for this large-scale temporalization to have global purchase, it must be qualified in relation to shifting conjunctures and scales of capitalism, distinct political forms, and counterhegemonic internationalist projects. Until the mid-twentieth century, the dominant scale of governance, capitalism, and techno-institutional assemblages was, for instance, that of empire and not the bounded nation form. Anti-imperialism and the multiple projects of decolonization it spawned across distinct conjunctures cannot then be confined to a moral or normative domain. They had profound cumulative (if not irreversible) consequences for the substantive reconfiguration of capital and sovereignty, on the one hand, and the articulation of collective institutions and modes of politics, on the other. Consider, for instance, the animating goals of the New International Economic Order led by Third World states (under the leadership of Latin American countries whose decolonization had preceded that of Asia, Africa, and the Middle East), which sought to wrest effective territorial and institutional sovereignty over economic resources and strategies of development in the decade that Maier sees as marking the beginning of the end of the age of territoriality. ${ }^{17}$ This was a robust counter-imperial project of political-economic sovereignty that extended territoriality in the vertical direction that Gabrielle asks us to consider, insofar as they foregrounded questions of the ownership and management of "natural" resources from rare-earth minerals to fossil fuels. It

15 Popular neoliberal globalist works include Kenichi Ohmae, The End of the Nation-State: The Rise of Regional Economies (New York, 1996); Ohmae, The Borderless World: Power and Strategy in the Interlinked Economy (New York, 1999); Thomas L. Friedman, The World Is Flat (New York, 2005). For a strong critique, see Neil Brenner, "Beyond State-Centrism? Space, Territoriality, and Geographical Scale in Globalization Studies," Theory and Society 28, no. 1 (1999): 39-78; and David Harvey, The Limits to Capital (Oxford, 1982).

${ }^{16}$ Maier, "Consigning the Twentieth Century to History," 816.

17 Samir Amin, "Self-Reliance and the New International Economic Order," Monthly Review 29, no. 3 (1977): 1-20; Amin, "After the New International Economic Order: The Future of International Economic Relations," Journal of Contemporary Asia 12, no. 4 (1982): 432-450; Greg Grandin, Empire's Workshop: Latin America, the United States, and the Rise of the New Imperialism (New York, 2006), chap. 5; Vanessa Ogle, "State Rights against Private Capital: The 'New International Economic Order' and the Struggle over Aid, Trade, and Foreign Investment, 1962-1981," Humanity: An International Journal of Human Rights, Humanitarianism, and Development 5, no. 2 (2014): 211-234. 
is hard to imagine the subsequent global immanence of neoliberal economic creeds and modes of governance without reference to the orchestrated defeat of this project.

Maier's essay forces us to acknowledge that even as histories of major events, struggles, and artifacts of the twentieth century proliferate-from mass revolution and total war to liberal internationalism and human rights discourses-basic temporal and spatial considerations remain contested. Since the essay first appeared, some shifts within the still-vital genre of "histories of the twentieth century" are already apparent. If the denouement of communism and the Cold War dominated the first wave of post-1989 reckonings with the twentieth century, historical assessments set nearer the millennium fronted questions of globalization and sovereignty, civil society and cosmopolitanism. ${ }^{18}$ More recently still, following speculative boom-and-bust cycles across world regions, the political-economic transcripts of intensifying social inequality, ecological and racial dispossessions, and the imperilment of democratic institutions have animated expanding waves of historical and historically minded research. ${ }^{19}$ We should expect, in other words, the twentieth century-both "what happened and what was said to have happened," to borrow the Haitian historical anthropologist's Michel-Rolph Trouillot's gloss on historical practice-

Jonathan Zatlin: Maier's essay was well timed, well considered, and well written. It raises important questions about the historical coherence of the twentieth century at its chronological close. Perhaps more importantly, it throws into relief the perils of periodization, warning against imposing present concerns onto the recent past. It also usefully disentangles structural from moral narratives. But as an attempt to offer a working alternative to existing periodicity, I don't find Maier's notion of “territoriality” compelling.

Manu has provided us with a powerful critique of its state-centered narrative. Both Gabrielle and Andrew commented insightfully, if skeptically, on the conceptual "breadth" of territoriality. Gabrielle's suggestion for "lengthening" it and Andrew's for including its exclusions enhance the flexibility of Maier's period. But I want to argue that this very flexibility is the problem. To construct a discrete historical division in time that is also capacious enough to incorporate the intellectual diversity of current inquiry, Maier is forced to dilute the conceptual features of his periodic framework. He does so in part, as Manu notes, by removing capitalism from his equation. But the more relevant he makes "territoriality" to the proliferation of histories that are now possible to imagine, the more he must sacrifice theoretical imagination and analytical rigor, which are what lend periodization its explanatory power.

${ }^{18}$ C. A. Bayly, The Birth of the Modern World, 1780-1914: Global Connections and Comparisons (Cambridge, 2004); Sudipta Kaviraj and Sunil Khilnani, Civil Society: History and Possibilities (Cambridge, 2001); Jürgen Osterhammel and Niels P. Petersson, Globalization: A Short History, trans. Dona Geyer (Princeton, N.J., 2005); Manuel Castells, The Rise of the Network Society (Malden, Mass., 2000); Jürgen Habermas, The Postnational Constellation: Political Essays, trans. and ed. Max Pensky (Cambridge, Mass., 2001); Michael Hardt and Antonio Negri, Empire (Cambridge, Mass., 2001).

${ }^{19}$ Wendy Brown, Undoing the Demos: Neoliberalism's Stealth Revolution (Cambridge, Mass., 2015); David Harvey, Spaces of Capital: Towards a Critical Geography (New York, 2001); Frederick Cooper, "What Is the Concept of Globalization Good For? An African Historian's Perspective," African Affairs 100, no. 399 (2001): 189-213; Charles Tilly, Durable Inequality (Berkeley, Calif., 1999); Thomas Piketty, Capital in the Twenty-First Century, trans. Arthur Goldhammer (Cambridge, Mass., 2014).

${ }^{20}$ Michel-Rolph Trouillot, Silencing the Past: Power and the Production of History (Boston, 1995), 5. 
I'm not suggesting that Maier's proposal is without utility, or that we should return to older ideas such as "modernity." Nor do I think "the twentieth century" will suffice even as a placeholder, not least because it is the product of a Christological reckoning with time that is hardly accepted throughout the world. Rather, I detect at the heart of Maier's proposal the urge to construct a common narrative, a need that is itself constructed by the transitional period we're living in. The economic and technological forces that are bringing the world closer together are at the same time driving people further apart, as differential vulnerabilities to cultural uniformity, environmental pollution, and income inequality widen existing gulfs. For professional historians, this dialectic has meant among other things a fleeting nostalgia for unifying narratives amid the polysemic din. ${ }^{21}$ Yet the growing integration of peoples, places, and things into new historical narratives necessarily disrupts intellectual consensus, while the proliferation of histories collaborates in the growing fragmentation of older and established hierarchies of meaning. It isn't enough, I think, merely to insert capitalism or to replace the state with the market — even if I very much like the idea based on my own intellectual preoccupations.

Instead, I want to focus on the tale itself, which is one of declension and decentered meaning. Maier's distinction between structural and moral narratives is useful, but neglects the ways in which narratological choices overdetermine the way that we recount history. ${ }^{22}$ Those choices, when left unanalyzed, make it possible to ignore the cultural embeddedness of the background against which they're told (such as presenting "the twentieth century" as a mere arithmetic division in time). The growing desire to sell books to a public that prefers narrative to argument has only aggravated existing ten-

${ }^{21}$ Maier's article, for example, presents territoriality as a kind of least common denominator to which historians working in various fields can all subscribe. At its finest, Marxist history generates a similar sensation of coherence despite its preoccupation with the state (Eric Hobsbawm, The Age of Extremes: The Short Twentieth Century, 1914-1991 [New York, 1994]), while economic history remains committed to overarching explanations of economic growth (see most recently the fascination with the intergenerational transmission of various kinds of capital, from Carmen M. Reinhart and Kenneth S. Rogoff, "Growth in a Time of Debt," American Economic Review 100, no. 2 [2010]: 573-578, and Piketty, Capital in the Twenty-First Century, to Maristella Botticini and Zvi Eckstein, The Chosen Few: How Education Shaped Jewish History, 70-1492 [Princeton, N.J., 2012]). Significantly, works that strike historians as "bad" are often perceived as such because the master narrative they advocate lacks causal flexibility (Daniel Jonah Goldhagen, Hitler's Willing Executioners: Ordinary Germans and the Holocaust [New York, 1996]) or critical distance (Arno J. Mayer, Why Did the Heavens Not Darken? The "Final Solution" in History [New York, 1988]). But perhaps the interest in master narratives has simply become a left-wing or liberal lapsus. Whatever the case, Mark Mazower manages to subordinate a larger argument about the weakness of interwar social compacts to the larger story of European destruction in his breathtaking synthetic work Dark Continent: Europe's Twentieth Century (New York, 1999), a feat he did not achieve in Hitler's Empire: How the Nazis Ruled Europe (New York, 2008).

22 In addition to Hayden White's work (particularly "The Fictions of Factual Representation," in Anna Green and Kathleen Troup, eds., The Houses of History: A Critical Reader in Twentieth-Century History and Theory [Manchester, 1999], 214-229, and "The Value of Narrativity in the Representation of Reality," in White, The Content of the Form: Narrative Discourse and Historical Representation [Baltimore, 1987], 1-25) and the work of Jacques Derrida (particularly "White Mythology: Metaphor in the Text of Philosophy," in Derrida, Margins of Philosophy, trans. Alan Bass [Chicago, 1982], 207-271), I'm thinking of F. R. Ankersmit's attempt to make sense of historicity (see especially "Historicism: An Attempt at Synthesis," History and Theory 34, no. 3 [1995]: 143-161), Amos Funkenstein's brilliant ruminations on the construction of historical narrative (perhaps most powerfully in "History, Counterhistory, and Narrative," in Saul Friedlander, ed., Probing the Limits of Representation: Nazism and the "Final Solution" [Cambridge, Mass., 1992], 66-81), and Slavoj Žižek's conceptualization of narrative as authorial enactment (Žižek, "The Truth Arises from Misrecognition," in Ellie Ragland-Sullivan and Mark Bracher, eds., Lacan and the Subject of Language [New York, 1991], 188-212). 
sions between analysis and storytelling inherent in historical work. Those tensions also shape the rift between our research and our teaching; it seems to me that they were felt even more strongly when undergraduate enrollments in history fell after the collapse of European communism had subsided and the capitalist world could return to its "work." Whatever the periodization we construct, however broadly it might appeal, it must mind these gaps.

Elizabeth F. Thompson: I wish to engage the conversation on Maier's use of territoriality to define an epoch, roughly 1860 to 1960. Gabrielle, Andrew, Manu, and Jonathan have raised compelling criticisms about the limits (two-dimensional) of the concept, about the linkage of its demise to weakness of moral claims, about delinking the history of the nation-state from that of capitalism, and about dilution of the concept to the point that it loses explanatory power.

I find most compelling Manu's reference to Henri Lefebvre's The Production of Space, which, she notes, argues that "capitalism, along with the state, relies upon the continual production and management of a diverse and hierarchically ordered ensemble of spaces." Indeed, as Manu suggests, the normative political unit for much of the world's population through 1960 remained empire, not nation-state. Moreover, most of the globe's peoples have since still largely failed to secure the level of national sovereignty that Maier claims defined his century. While Maier nods to historians of nonEurope, his argument remains fundamentally Eurocentric.

Like Gabrielle and Andrew, I also question Maier's decoupling of analytical and structural narratives. From the viewpoint of the Middle Eastern societies I study, the two narratives are tightly conjoined in what I would call the long twentieth century. World War I opened an era of global mass politics, in which non-Europeans have strived for equal rights with Europeans and North Americans. ${ }^{23}$ The century is defined by the latter's effort to relegate those peoples to a lesser rung of humanity, civilization, race, beginning with the treaties imposed after World War I. It is this struggle that has underpinned the major conflicts and mass murders of the century, as well as its brightest moments of hope-for example, at the United Nations in 1948, in the United States in 1965, and in South Africa in 1994. The Arab Spring uprisings of 2011 were all animated by peoples seeking the dignity of human rights and equal portions of bread-a dignity denied them in the very transnational world system that assured unequal access to global markets and capital and that forced them to live under externally supported dictatorships, whether in the colonial or Cold War eras.

The peoples of the Middle East did not feel the passing of an era in the late twentieth century, contrary to Maier's or Eric Hobsbawm's view. ${ }^{24}$ For them, territoriality has remained a long-deferred dream, not a memory. Like so many across the less industrialized world, Arabs have been fighting "distributive social conflicts" since the 1920s,

${ }^{23}$ Michael Goebel, Anti-Imperial Metropolis: Interwar Paris and the Seeds of Third World Nationalism (New York, 2015); Elizabeth F. Thompson, Justice Interrupted: The Struggle for Constitutional Government in the Middle East (Cambridge, Mass., 2013); Adria K. Lawrence, Imperial Rule and the Politics of Nationalism: Anti-Colonial Protest in the French Empire (New York, 2013); Marilyn Lake and Henry Reynolds, Drawing the Global Colour Line: White Men's Countries and the International Challenge of Racial Equality (New York, 2008); Erez Manela, The Wilsonian Moment: Self-Determination and the International Origins of Anticolonial Nationalism (New York, 2009).

${ }^{24}$ Hobsbawm, The Age of Extremes. 
not since the 1980s, as Maier would have it. Non-Europeans recall many more moral atrocities than those committed under Stalin and Hitler: those of the Young Turks in 1915, of Hiroshima in 1945, of the repeated famines in British India, of Algeria, and the bloodletting of proxy wars in Vietnam and Southwest Africa, and so on. In this perspective, today's collapse of Arab states and flow of migrants into Europe appear to play out in terms of European-American hegemony reasserted so problematically in Paris in 1919. Is the long twentieth century soon to end?

Adeeb Khalid: Maier is absolutely right to question the value of periodizations based simply on chronology and presents us with the notion of "territoriality" as marking a period that would be of help in understanding key structural transformations of modern history. While I agree in large measure with Maier's point, I don't see how territoriality is the only feature for analyzing history, or indeed if we can be so sure of its passing. True enough that contemporary states cannot see the control of territory as quite so fundamental a part of their resources, but surely the archipelago of U.S. military bases around the world and its flotillas of satellites and drones have something to do with the control of space, a control that structures the contemporary world order. We can also find vectors other than territoriality that would lead to other conceptualizations of time frames for understanding the world we live in.

And I agree with those who have called into question the sustainability of the distinction between "moral" and "structural" narratives that Maier posits. In this vein, Elizabeth Thompson is quite right to point out that Maier's "argument remains fundamentally Eurocentric." The history of non-Western peoples trying to assert their presence in the world is perhaps a fundamental feature of the recent past. Whether it took the form of state-centric efforts such as those launched at Bandung in 1955 or, perhaps more significantly, of counter-state radical movements such as socialism and (other) "national liberation movements," the search for equality and for overturning the order imposed by empire is a defining feature of the era. It has taken many forms and produced different kinds of results, both noble and ignoble. It has taken different paths, whether those of emulation ("mimicry") or rejection of Europe (and the consequent search for "authenticity"), or of anything in between. ${ }^{25}$ Surely this is where we might search for a "constellation of events" that had major significance for large numbers of actors in the recent past and that can be seen to constitute a distinct era.

Whether that era is past is a different question, and a difficult one to answer. Certainly in teaching American undergraduates, it is clear that the worlds of proletarian organization, Third-Worldism, import substitution, and the search for alternatives to the (neo)liberal order are long gone. They appear to my students to be as distant and as exotic (if not more so) as those of the Middle Ages. Yet, as Elizabeth reminds us, the questions of human and national dignity are still very salient to many peoples in the world today, even if the answers today are posed differently. Mass utopia, indeed, has passed (as Susan Buck-Morss pointed out a decade ago). ${ }^{26}$

\footnotetext{
25 The literature on national movements, nation-state building, and decolonization is vast. Pankaj Mishra's recent work From the Ruins of Empire: The Revolt against the West and the Remaking of Asia (London, 2012) provides an admirable synthesis and overview.

${ }^{26}$ Susan Buck-Morss, Dreamworld and Catastrophe: The Passing of Mass Utopia in East and West (Cambridge, Mass., 2000).
} 
Anna Krylova: Maier's essay happens to resonate with me much more strongly in 2016 than when I first read it more than a decade ago. What resonates is not Maier's attempt at creating what Gabrielle so fittingly characterized as "a primary periodization tool"- - the master concept of "territoriality" - with which Maier hoped to resist persistent "moral stories" about the twentieth century as well as the moralizing propensity of the historian's craft itself. Though I cannot help but admire the intellectual boldness of such an undertaking, I also share Andrew's, Gabrielle's, and Jonathan's reservations about its analytical purchase. I wonder whether an intellectual agenda aiming at creating a "primary tool" of historical periodization and narration even for one epoch can ever be anything but an invariably limiting and vulnerable analytical undertaking, as Manu and Elizabeth have argued.

What resonates with me is not Maier's proposed solution to the "metaphorical suggestiveness" (which, I believe, we are to read as analogical, descriptive, and shallow) of moral narratives, but his critique of the moralizing narrative itself as a consistent problem of historiography, the problem that is worth, I think, reconsidering and reformulating in relation to our current historiographies of the twentieth century. Building on Alex's remarks, I wonder if we could turn the question of whether the twentieth century will "cohere as a historical epoch" into a question of what has been happening to the "twentieth century" in our respective fields over the past fifteen years. What narratives (moralizing or not so moralizing) have cohered? What old metaphors-these discursive anchors around which moral stories congeal-have proven indispensable? What new metaphors have become warranted?

It seems to me that one can productively pursue these questions without falling into Maier's rather problematic treatment of moral and structural narratives as countering modes of analysis.

AHR Editor: As I read your initial responses to the Maier article, I found myself wondering how we could think more about the innovations in techniques of power (Gabrielle uses the term "technopolitical") that marked twentieth-century lives. Attention to such techniques-theorized as "biopower," "high modernism," or "the production of space," to name but three influential examples-may help get us beyond state-centered and mere geographic explanations of "territoriality." 27 This more diffuse approach may move us instead toward the kinds of issues some of you gesture at: "verticality," the definition, control, and movement of populations, the archipelagic ability to dominate non-contiguous territories, alternative narratives or "emplotment." Yet attention to such repertoires of power still permits the construction of both moral narratives and structural explanations, though perhaps in novel registers. Could each of you speak to how, from the perspective of developments in your own field and/or research, historians have explored or defined such emergent techniques of power to come to grips with the twentieth century?

${ }^{27}$ Michel Foucault, Security, Territory, Population: Lectures at the Collège de France, 1977-1978, ed. Michel Senellart, trans. Graham Burchell (New York, 2007); Foucault, The Birth of Biopolitics: Lectures at the Collège de France, 1978-1979, ed. Michel Senellart, trans. Graham Burchell (New York, 2008); James C. Scott, Seeing Like a State: How Certain Schemes to Improve the Human Condition Have Failed (New Haven, Conn., 1998); Lefebvre, The Production of Space. 
Andrew Zimmerman: The emergence of techniques of power as a topic distinct from political movements is not only an optic through which to consider the twentieth century but also an artifact of the late twentieth century. This perspective, whose most important theorist was Foucault, is closely related to the neoliberal moral narrative that Maier discussed: power is always suspect, always on the side of the oppressor, and liberation consists in individuals avoiding this power but not exercising their own (except in the market or "civil society"). Agamben's notion of homo sacer, in which the modern political subject is bare life, in fact only an object of politics, is perhaps the perfected form of this misarchism. ${ }^{28}$ Hannah Arendt, who was, I think, Agamben's best theoretical source, had a better model of power, which emphasizes the creative politics of the insurgent people, with state, capital, and other forms of oppression as depoliticizing forces. And for Arendt, the great political technique, which can only be exercised by this insurgent power, is the workers' council, for example in the soviets of the Russian Revolutions (particularly before Kronstadt) and in the 1956 Hungarian Revolution. ${ }^{29}$ Coming to the twentieth century from my own area of specialty-the nineteenth century-I would trace this technique of power in Europe to the Paris Commune (so brilliantly analyzed by Kristen Ross in her recent book) and, centuries before Europeans caught on, to the variety of Maroon and other political forms created by people of African descent within and against slavery and racial capitalism—forms my colleague Jessica Krug terms "fugitive modernities." 30

Elizabeth F. Thompson: A brief sociopolitical look at the Middle East reveals a region where it is difficult to displace the state's overwhelming assertion of power in the twentieth century. From the perspective of state techniques of power, the twentieth century makes sense as a distinct and tragic historical period. World War I and the subsequent colonization in the Arab world initiated a new era. By the turn of the century, the former Ottoman state had developed a rudimentary intelligence network of spies, who funneled data to Istanbul through telegrams and photos. In retrospect, its methods of surveillance and repression were both quaint (Sultan Abdulhamid loved Sherlock Holmes stories) and simply brutal (as in massacres of Bulgarians and Armenians). In the decade of war from 1911 to 1921, however, the Turks systematized methods of control and repression so as to engineer a genocide of Armenians and to keep the halfstarved populations of rural Anatolia and the Arab provinces subservient. Contrary to Europe, there were no outright mutinies in the army, only a growing tide of desertion. As in Europe, the wartime state became a terrible dictatorship, ruthless in its repression and highly centralized in controlling national resources. The state appropriated private property at will, and quarantined noncompliant elites. It used terror to quash

${ }^{28}$ Giorgio Agamben, Homo Sacer: Sovereign Power and Bare Life, trans. Daniel Heller-Roazen (Palo Alto, Calif., 1998). The term "misarchism" is from Friedrich Nietzsche, On the Genealogy of Morality, ed. Keith Ansell-Pearson, trans. Carol Diethe (Cambridge, 2007), II:12.

${ }^{29}$ Hannah Arendt, On Revolution (1963; repr., New York, 2006).

${ }^{30}$ Kristen Ross, Communal Luxury: The Political Imaginary of the Paris Commune (London, 2015); Jessica A. Krug, “'They Glorify in a Certain Independence': The Politics of Identity in Kisama, Angola, and Its Diasporas in the Sixteenth and Seventeenth Centuries" (Ph.D. diss., University of WisconsinMadison, 2012); Krug, "Social Dismemberment, Social (Re)membering: Obeah Idioms, Kromanti Identities, and the Trans-Atlantic Politics of Memory, c. 1675-Present," Slavery and Abolition 35, no. 4 (2014): $537-558$. 
opposition, as with the mass executions of Arab notables at Beirut and Damascus in 1915 and 1916. ${ }^{31}$

Unlike Europe, liberal political forces were permitted little room for a corrective after the 1918 armistice. The threat and then reality of European occupation extended militarized governance into the postwar era. Most remarkable among Arab mandates established from remnants of the Ottoman Empire was the fusion of state administration with intelligence from the inception of the regimes. As Martin Thomas has shown in Syria, even health and education ministries funneled data directly to secret police. As Priya Satia has shown in Iraq, the British adopted cost-cutting measures of carpetbombing resistant populations. As I and others have demonstrated, the Royal Air Force developed techniques in "peacetime" Iraq that would be perfected at Dresden in World War II. ${ }^{32}$ Even after Iraq won nominal independence in 1932, the British retained control of internal security apparatuses, which practiced torture at Abu Ghraib prison in the 1940s. Iraq's only truly national political party, the Iraqi Communist Party, developed only because its leader had learned techniques of underground organizing in Moscow. The party gained a following of more than a million members by the time of the 1958 coup that finally chased the British from the country. ${ }^{33}$ The British used similar methods in Palestine against Arabs, in the 1936-1939 revolt, initiating the tactic of bombing homes of suspected activists that was later used by Israel.

Independent Arab regimes established in the second half of the twentieth century adopted this militarized/colonial DNA to produce the regimes of terror under Saddam Hussein, Hafez al-Assad in Syria, Muammar Qaddhafi in Libya, and Gamal AbdelNasser in Egypt. Historical sociologists and political scientists like David Waldner, Steven Heydemann, Lisa Wedeen, Tim Mitchell, Hanna Batatu, and Joseph Sassoon have shown how postcolonial Arab states harnessed their colonial legacy to the new technologies of one-party rule, hollowing out what remained of an independent, law-abiding, civilian bureaucracy. ${ }^{34}$ To establish and maintain power, these military dictatorships imposed heavy control over agricultural and industrial production as well. The Arab Spring of 2011 rose up against the cancerous growth of secret police and brutality in these states, and against their consequent intolerance of the free markets that would foster economic development. A most optimistic view of the current chaos in the Arab world is that it represents the unraveling of techniques of power born a century ago.

${ }^{31}$ M. Talha Çiçek, War and State Formation in Syria: Cemal Pasha's Governorate during World War I, 1914-17 (New York, 2014); Erik J. Zürcher, The Young Turk Legacy and Nation Building: From the Ottoman Empire to Atatürk's Turkey (New York, 2010); Uguru Ümit Üngör, The Making of Modern Turkey: Nation and State in Eastern Anatolia, 1913-1950 (New York, 2012).

${ }^{32}$ Martin Thomas, Empires of Intelligence: Security Services and Colonial Disorder after 1914 (Berkeley, Calif., 2007); Priya Satia, Spies in Arabia: The Great War and the Cultural Foundations of Britain's Covert Empire in the Middle East (New York, 2008); Elizabeth F. Thompson, "Déjà vu in the Middle East: The Not So New Face of War," paper presented at Historians Against the War National Conference, Towson, Md., April 5 -7, 2013.

33 Thompson, Justice Interrupted, chap. 7.

${ }^{34}$ David Waldner, State Building and Late Development (Ithaca, N.Y., 1999); Steven Heydemann, Authoritarianism in Syria: Institutions and Social Conflict, 1946-1970 (Ithaca, N.Y., 1999); Lisa Wedeen, Ambiguities of Domination: Politics, Rhetoric, and Symbols in Contemporary Syria (Chicago, 1999); Timothy Mitchell, Rule of Experts: Egypt, Techno-Politics, Modernity (Berkeley, Calif., 2002); Hanna Batatu, The Old Social Classes and the Revolutionary Movements of Iraq: A Study of Iraq's Old Landed and Commercial Classes and of Its Communists, Ba'thists, and Free Officers (London, 2004); Joseph Sassoon, Saddam Hussein's Ba'th Party: Inside an Authoritarian Regime (New York, 2011). 
Gabrielle Hecht: Andrew's observation about the twentieth-century origins of "techniques of power" is particularly apt for the history of technology—even though the genealogy of that subdiscipline largely bypasses Foucault. The field emerged in the 1950s, in part to counter the history of science's epistemological privileging of dematerialized knowledge production, and in part in responding to anxieties pervading Cold War engineering education. The first generation of technology historians sought to challenge technological determinism in multiple venues (including historical scholarship, engineering practice, and popular discourse). ${ }^{35}$ Thomas Parke Hughes's study of electrification in Germany, Britain, and the U.S. was particularly influential in pushing historians to think about industrial technologies in a "seamless web" of politics, hardware, institutions, and geography. In the 1980s, his study of sociotechnical systems gained traction among sociologists and others in the emerging field of science and technology studies (STS). ${ }^{36}$

While tightly coupled systems (such as railroads and telegraphs) had their origins in the nineteenth century, it was the twentieth century that witnessed the rapid spread and dense interconnection of sociotechnical systems, and that's where the bulk of research has concentrated. Over time, scholars have explored sociotechnical systems (along with "assemblages" and "infrastructures") in order to address broad historical themes such as nation-building, war, the making of Europe, expertise and democracy, gender, and much more. ${ }^{37}$ One especially interesting strand-relevant to our discussion of territoriality and verticality—concerns the forms of governance and modes of political contestation produced by the emergence of "cosmopolitan commons" such as airspace, radio waves, or undersea oil reserves. ${ }^{38}$

In these conversations, STS scholars are particularly interested in the stuff of politics. Can technology be understood as "politics by other means"? That formulation assumes that politics and technology influence each other but remain ontologically distinct. Another view-which I gloss as technopolitics-sees particular technological forms and practices as ontologically inseparable from (a) the political negotiations that produce them and/or (b) the politics that they enact or permit. In an early analysis along these lines, sociologist Donald MacKenzie offered a radical reinterpretation of Cold War nuclear strategy, arguing that policies such as mutually assured destruction, counterforce targeting, and other aspects of deterrence resulted not from high-level decision-making by policymakers, but rather from an accumulation of small choices made

${ }^{35}$ For a history of the field, see Bruce E. Seely, "SHOT, the History of Technology, and Engineering Education," Technology and Culture 36, no. 4 (1995): 739-772. Debates about technological determinism are captured in Leo Marx, ed., Does Technology Drive History? The Dilemma of Technological Determinism, ed. Merritt Roe Smith and Leo Marx (Cambridge, Mass., 1994).

36 Thomas P. Hughes, Networks of Power: Electrification in Western Society, 1880-1930 (Baltimore, 1983). Subsequent debates played out in volumes such as Wiebe E. Bijker, Thomas P. Hughes, and Trevor J. Pinch, eds., The Social Construction of Technological Systems: New Directions in the Sociology and History of Technology (Cambridge, Mass., 1987); Wiebe E. Bijker and John Law, eds., Shaping Technology/Building Society: Studies in Sociotechnical Change (Cambridge, Mass., 1994).

37 On the role of technological systems in modern European history, see the Palgrave Macmillan series "Making Europe: Technology and Transformations, 1850-2000," including Ruth Oldenziel and Mikael Hård, Consumers, Tinkerers, Rebels: The People Who Shaped Europe (New York, 2013), and Per Högselius, Arne Kaijser, and Erik van der Vleuten, Europe's Infrastructure Transition: Economy, War, Nature (Basingstoke, 2016). On gender, see Nina E. Lerman, Ruth Oldenziel, and Arwen Mohun, eds., Gender and Technology: A Reader (Baltimore, 2003), among many other works.

38 Nil Disco and Eda Kranakis, Cosmopolitan Commons: Sharing Resources and Risks across Borders (Cambridge, Mass., 2013). 
by weapons designers striving toward greater missile accuracy. ${ }^{39}$ Inspired by his analysis, I made a similar argument concerning France's nuclear program, showing how its atomic bombs took shape in the cores of its earliest reactors, years before French politicians made a "decision" to develop a nuclear weapons program. ${ }^{40}$ French nuclear institutions pursued contrasting technopolitical regimes, which enacted different visions of national identity, expert rule, labor, and democracy. ${ }^{41}$ Historians have also used this approach to deprovincialize the Cold War, gaining insight into such topics as the "networked empire" of U.S. island military bases, the technopolitics of dissent in Saudi Arabia's oil/water complex, or Zimbabwe's anticolonial struggle. ${ }^{42}$

Technopolitics became a privileged mode of state power in the twentieth centurynot just in metropoles, but also in empires and postcolonies-because it could be an effective tool of depoliticization, displacing negotiation and struggle into technical realms where few could claim authority. Timothy Mitchell (whom Elizabeth also invoked) analyzed the "rule of experts" in Egypt by exploring the Aswan Dam and other large-scale endeavors; the genealogy of his "technopolitics" passes through Foucault more than it does STS. ${ }^{43}$ But technopolitical power isn't hegemonic, nor is it limited to the state, and the displacements it effects can be challenged. Brian Larkin examines media in Nigeria, showing how the state, colonial subjects, and postcolonial citizens used radio and other media as technopolitical instruments, shaping strategies, outcomes, and experiences. ${ }^{44}$ Workers and other citizens who confront technopolitical power in their daily lives have themselves developed technopolitical modes of survival, resistance, and claims-making. Uranium miners in Namibia deployed their own technopolitical strategies when linking their unionization efforts to the broader national liberation struggle. Indeed, technopolitical strategies played an important role in the international antiapartheid movement-both in the implementation of sanctions against military and computer equipment, and in specific operations of sabotage and communication. ${ }^{45}$

Jonathan Zatlin: Marked by the collapse of an empire and the failure of a democratic state, two World Wars and two dictatorial regimes, Germany's tumultuous twentieth century has provided unusually fertile grounds for thinking about techniques of power. It is no accident, for example, that German-speaking social scientists were among the most significant contributors to totalitarianism theory, perhaps the most influential product of Cold War political thought. From Karl Popper and Hannah Arendt

${ }^{39}$ Donald MacKenzie, Inventing Accuracy: A Historical Sociology of Nuclear Missile Guidance (Cambridge, Mass., 1993).

${ }^{40}$ Gabrielle Hecht, The Radiance of France: Nuclear Power and National Identity after World War II (Cambridge, Mass., 1998).

${ }^{41}$ See also Sara B. Pritchard, Confluence: The Nature of Technology and the Remaking of the Rhône (Cambridge, Mass., 2011).

${ }^{42}$ Ruth Oldenziel, "Islands: The United States as a Networked Empire," in Gabrielle Hecht, ed., Entangled Geographies: Empire and Technopolitics in the Global Cold War (Cambridge, Mass., 2011), 1342; Toby Craig Jones, Desert Kingdom: How Oil and Water Forged Modern Saudi Arabia (Cambridge, Mass., 2011); Clapperton Chakanetsa Mavhunga, Transient Workspaces: Technologies of Everyday Innovation in Zimbabwe (Cambridge, Mass., 2014).

${ }^{43}$ Mitchell, Rule of Experts. 2008).

${ }^{44}$ Brian Larkin, Signal and Noise: Media, Infrastructure, and Urban Culture in Nigeria (Durham, N.C.,

${ }^{45}$ Gabrielle Hecht, Being Nuclear: Africans and the Global Uranium Trade (Cambridge, Mass., 2014); Paul N. Edwards and Gabrielle Hecht, "History and the Technopolitics of Identity: The Case of Apartheid South Africa,” Journal of Southern African Studies 36, no. 3 (2010): 619-639. 
to Carl Friedrich and Karl Dietrich Bracher, the various iterations of the theory shared an emphasis on the malleability of populations through ideological mobilization, punitive surveillance, and bureaucratic rationality that bore all the marks of their encounter with National Socialism even as it served to defend the liberal state from its illiberal opponents. ${ }^{46}$

In contrast, historians focused on periodization as a way to work through the traumatic consequences of National Socialism and a genocide that, at first, received only oblique mention. The direct experience of German fascism led many to invert previously positive narratives of German exceptionalism (as either a more progressive or a more national state than its British, French, and Russian competitors) and view German history instead as moving along a disastrous "special path" (Sonderweg) to Hitler. As a result, much scholarship after the war recruited all sorts of evidence to explain the inevitability of 1933. The organizing clarity and conceptual distortions of this approach are perhaps most obvious in Hans-Ulrich Wehler's brilliant synthetic history The German Empire, 1871-1918 (1973), which succeeds in reducing nineteenth-century German history to a tale of incomplete modernization and charismatic dictatorship, Bismarckian carpe diem to Hitler ante portas, and 1918 to 1933, as if Weimar were a mere rest stop on the way to the real destination. ${ }^{47}$ Even excursions into comparative history were organized by this teleology of aberrance. More direct challenges to the Sonderweg sought to wrest German history from the grip of exceptionalism only to reinscribe the centrality of the state as a source for organizing their narrative. Perhaps for this reason, Peter Pulzer, one of the more astute historians of German politics, could conclude in a statement of dialectical defiance that "all German regimes have been attempts to counter the mistakes of the previous one." 48

By the 1980s, however, historians had begun to look beyond the state for clues about German society. The mounting challenge to the Sonderweg was most famously captured by David Blackbourn and Geoff Eley's Peculiarities of German History (1984), which attacked the concept of German deviance by undermining the normative status of Germany's putative developmental other, Great Britain, and shifting focus away from electoral politics to civil society for evidence of democratic practice. If the book

${ }^{46}$ K. R. Popper, The Open Society and Its Enemies (London, 1945); Hannah Arendt, The Origins of Totalitarianism (New York, 1951); Arendt, Eichmann in Jerusalem: A Report on the Banality of Evil (New York, 1963); Carl J. Friedrich and Zbigniew K. Brzezinski, Totalitarian Dictatorship and Autocracy (Cambridge, Mass., 1956); Karl Dietrich Bracher, Die Auflösung der Weimarer Republik: Eine Studie zum Problem des Machtverfalls in der Demokratie (Stuttgart, 1955).

${ }^{47}$ Hans Ulrich Wehler, Das deutsche Kaiserreich, 1871-1918 (Goüttingen, 1973). Before 1945, the notion of a special German path was positioned positively. See, for example, the fascinating attempt by Heinrich von Sybel, an influential Prussian historian and nationalist politician who would be appointed by Bismarck to oversee the Prussian state archives, to make the new German Empire seem democratic to the British public: Sybel, "The German Empire," Fortnightly Review, new series, 9, no. 49 (January 1, 1871): 1-16. After the creation of the "Third Reich," however, Nazi aggression was widely located by many non-Germans in longer historical trends. See, for example, Lewis Bernstein Namier's brilliant lectures on the revolution of 1848, 1848: The Revolution of the Intellectuals (London, 1944); and A. J. P. Taylor, The Course of German History: A Survey of the Development of German History since 1815 (London, 1945). Fritz Fischer was among the first German historians to provide clear evidence of predatory continuities in German foreign policy across Imperial, Weimar, and Nazi Germany, undermining attempts to treat the Nazis as a deviation; Fischer, Griff nach der Weltmacht: Die Kriegszielpolitik des kaiserlichen Deutschland, 1914/18 (Düsseldorf, 1961), which appeared in English as Germany's Aims in the First World War, trans. Hajo Holborn and James Joll (New York, 1968).

48 Peter Pulzer, German Politics, 1945-1995 (Oxford, 1995), 7. 
failed to banish the specter of German exceptionalism from the historiographic stage, it and more empirical work of the period freed historians up to view society beyond the state as worthwhile avenues for historical study. ${ }^{49}$

It was at this juncture, I would argue, that growing discomfort with totalitarianism theory combined to lead German historiography down a very different path. Perhaps most immediately, the collapse of German communism provided scholars access to archival sources and stimulated renewed interest in the difference between power and authority. Studies of the East German regime, from Catherine Epstein's work on the communist leadership and Andrew Port's analysis of dissent to Paul Betts's brilliant look at intimacy under dictatorial conditions and my own attempt to demonstrate the limits of communist control over economic practice, challenged standard depictions of communist power as complete. ${ }^{50}$ Around the same time, a reappraisal of the Nazi terror apparatus demolished the myth of a secret police whose omniscience and omnipotence rendered resistance impossible. Scholars such as Klaus-Michael Mallmann and Eric Johnson emphasized not only how small, but how entrepreneurial the Gestapo was-that Gestapo agents relied on denunciations, but were also encouraged to act on their own initiative and according to their own prejudices. ${ }^{51}$ Andrew's comment about Arendt as a source for Foucault is very insightful. But at least when it comes to the Stasi and the Gestapo, I think Arendt is being proven wrong and Foucault irrelevant.

From a very different perspective, one that integrates the experience of victims as well as perpetrators, recent work in economic history has opened new space for historical research by understanding the state as a significant and sometimes dominant, but never conclusive actor. The work of Jonathan Wiesen on the mental constructs informing Nazi economic practice, Pamela Swett on advertising and sales in the "Third Reich," Christoph Kreutzmüller on the Nazi destruction of the Jewish commercial presence in Berlin, and Malte Zierenberg on black markets in the "Third Reich" has changed our understanding of the relation between profit and prejudice, cementing the focus on non-state actors, widening the circle of culpability, and embedding economic practice in cultural history. 52

As the peculiarities of German history give way to its particularities, moreover, historians have begun to contextualize local idiosyncrasies by attending to transnational developments. Andrew's excellent book Alabama in Africa: Booker T. Washington, the German Empire, and the Globalization of the New South joins recent work by Timothy

${ }^{49}$ David Blackbourn and Geoff Eley, The Peculiarities of German History: Bourgeois Society and Politics in Nineteenth-Century Germany (Oxford, 1984).

50 Catherine Epstein, The Last Revolutionaries: German Communists and Their Century (Cambridge, Mass., 2003); Andrew I. Port, Conflict and Stability in the German Democratic Republic (Cambridge, 2007); Paul Betts, Within Walls: Private Life in the German Democratic Republic (Oxford, 2010); Jonathan R. Zatlin, The Currency of Socialism: Money and Political Culture in East Germany (Cambridge, 2007).

${ }^{51}$ Klaus-Michael Mallmann, Gestapo und Widerstand (St. Ingbert, 1992), as well as Klaus-Michael Mallmann and Gerhard Paul, eds., Die Gestapo: Mythos und Realität (Darmstadt, 1995); Eric A. Johnson, Nazi Terror: The Gestapo, Jews, and Ordinary Germans (New York, 1999). See also Frank Bajohr's superb dismantling of our perception of the Nazis as ruthless and efficient, Parvenüs und Profiteure: Korruption in der NS-Zeit (Frankfurt am Main, 2001), which has, lamentably, yet to find an English translation.

${ }^{52}$ S. Jonathan Wiesen, Creating the Nazi Marketplace: Commerce and Consumption in the Third Reich (Cambridge, 2011); Pamela Swett, Selling under the Swastika: Advertising and Commercial Culture in Nazi Germany (Stanford, Calif., 2014); Christoph Kreutzmüller, Final Sale in Berlin: The Destruction of Jewish Commercial Activity, 1930-1945 (New York, 2015); Malte Zierenberg, Berlin's Black Market, 1939-1950 (New York, 2015). 
Brown, Michael Meng, Quinn Slobodian, and a younger generation of scholars working on the GDR in connecting German history with larger trends in a way that makes it possible to think more clearly about specifically German problems. ${ }^{53}$ To my mind, what remains is a thoroughgoing consideration of the conceptual assumptions that continue to organize the narratives of German history along the lines of Anna Krylova's work, which has laid bare the continued and subtle projection of liberal subjectivity onto nonliberal subjects. Among the many other developments in other subfields, German historians have a great deal to learn from the discussion around subjectivity in Soviet history. ${ }^{54}$

Anna Krylova: In the field of modern Russian history, the introduction of the concept of "power" in the mid-1990s was indeed immediately allied with the conversation and theorization of the concept of "subjectivity." Learning how to use these two terms, the field underwent its cultural turn and, as a result, updated its methodological approaches and master narratives. In fact, given the particular formulation of "power" that the field embraced- "power" as a meaning-giving system of domination, that is, an ideology, culture, or discourse now understood as an inescapable system of signification embedded in state institutions and people's minds-it was impossible to invoke "power" without at once posing the question about the relationship between the Bolshevik project and the individual-its subject. Stephen Kotkin's 1995 reconceptualization of the prewar Stalinist period along these lines played a defining role in shaping the field's analytics not only for the Stalinist years but, as I have argued elsewhere, for the entire Soviet period. ${ }^{55}$

The understanding of Stalinism, in particular, produced by a generation of social historians of the 1970 s and 1980 s, as a period overcome by unruly social forces unleashed by the Soviet state, barely coping with the social ramifications of its modernizing projects (according to Moshe Lewin, for example, even Stalinist purges and extreme punitive measures carried out by the state had to be considered in the context of the state's failure to control the situation) - this vision was critiqued for its disregard of ideological and cultural dimensions of history. ${ }^{56}$ The new scenario offered an innovative concept of "Soviet modernity" as an actualization of the overpowering logic of the Bol-

53 Andrew Zimmerman, Alabama in Africa: Booker T. Washington, the German Empire, and the Globalization of the New South (Princeton, N.J., 2010); Timothy Scott Brown, West Germany and the Global Sixties: The Antiauthoritarian Revolt, 1962-1978 (Cambridge, 2015); Michael Meng, Shattered Spaces: Encountering Jewish Ruins in Postwar Germany and Poland (Cambridge, Mass., 2011); Quinn Slobodian, Foreign Front: Third World Politics in Sixties West Germany (Durham, N.C., 2012).

${ }^{54}$ Anna Krylova, "The Tenacious Liberal Subject in Soviet Studies," Kritika: Explorations in Russian and Eurasian History 1, no. 1 (2000): 119-146. See also Jochen Hellbeck, Revolution on My Mind: Writing a Diary under Stalin (Cambridge, Mass., 2006); Igal Halfin, Red Autobiographies: Initiating the Bolshevik Self (Seattle, Wash., 2011); and Alexis Peri's forthcoming book The War Within: Diaries from the Siege of Leningrad (Cambridge, Mass., 2017).

55 Stephen Kotkin, Magnetic Mountain: Stalinism as a Civilization (Berkeley, Calif., 1995); Anna Krylova, "Soviet Modernity: Stephen Kotkin and the Bolshevik Predicament," Contemporary European History 23, no. 2 (2014): 167-192.

56 Moshe Lewin, The Making of the Soviet System: Essays in the Soviet History of Interwar Russia (New York, 1985); Ronald Grigor Suny, The Making of the Georgian Nation (Bloomington, Ind., 1988); Sheila Fitzpatrick, Education and Social Mobility in the Soviet Union, 1921-1934 (Cambridge, 1979); Fitzpatrick, The Cultural Front: Power and Culture in Revolutionary Russia (Ithaca, N.Y., 1992); Stephen Kotkin, "1991 and the Russian Revolution: Sources, Conceptual Categories, Analytical Frameworks," Journal of Modern History 70, no. 2 (1998): 384-425. 
shevik ideological ideal. In this new historical drama, no one, except ideology/culture upgraded to the status of a system, was in control, and everyone and everything was a product and a tool, that is, a subject. Thus, not only "ordinary Soviet citizens" but also state and party leaders together with state and party institutions were, at the fundamental level, entrapped within the cultural tenets of Bolshevik modernity. Bolshevik modernity informed state policies and penetrated individuals' deepest layers of self-awareness and modes of self-expression. The resultant master narrative is by no means deprived of considerations of change. In fact, it has generated an impressive list of studies whose authors investigate shifts and modifications of the Soviet ideological project and its individual appropriations and misappropriations but do not question the project's and its subjects' presumed grounding in the Bolshevik ideal. ${ }^{57}$

The problem with this model (which, of course, is not unique to the recent historiography on Soviet socialism) that I want to foreground in light of our discussion is not only its treatment of the historical subject with all its imperfections and misappropriations as fundamentally a product of some ideological-cultural project. My dissatisfaction with the model is akin to Jonathan's and Andrew's. It has to do with the fact that it renders the theorization of the agency category as well as of the power-agency relationship irrelevant. The concept of subjectivity, a valuable analytical acquisition, does enable historians to analyze production, maintenance, and reproduction of desired subjects. But it does not offer much help when we are faced with such enigmatic phenomena, as far as our theoretical corpus is concerned, as resistance, insurgency, protest, and, most importantly, in my opinion, the possibility of critique and/or action outside of dominant cultural paradigms. In fact, ever since the concepts of power and subjectivity became operational, historians in and outside the Russian field have been questioning the treatment of the individual as a simple effect of power, but they have not always directly addressed the theoretical significance of their findings. The question that I am struggling to articulate is not about the possibility of historical agency. It is about how we as historians can account for historical agency without giving up on the concept of power and without giving in to ideological narratives featuring autonomous individuals living and willing their lives despite cultural systems and social circumstances.

Adeeb Khalid: Alex asks whether attention to new repertoires of power might help get us beyond state-centered explanations of "territoriality." It seems to me that in large parts of the world, the new techniques of power have been created and implemented by states themselves and cannot be understood independently of them. As Elizabeth points out, "the state's overwhelming assertion of power" is difficult to displace in the Middle East, and not just there. We need to remember that many in the colonized world actually envied new techniques of power and wished to possess them themselves for the sake of "progress," "overcoming backwardness," or achieving equality and dignity in the world. Anticolonialism was tied intimately to the search for new regimes of power that might bring to the colonized what made the colonizer so strong.

${ }^{57}$ Kotkin, Magnetic Mountain; Igal Halfin, From Darkness to Light: Class, Consciousness, and Salvation in Revolutionary Russia (Pittsburgh, 1999); Oleg Kharkhordin, The Collective and the Individual in Russia: A Study of Practices (Berkeley, Calif., 1999); Hellbeck, Revolution on my Mind. For an analysis stressing uneven mechanisms of individual internalization of Bolshevik-Soviet ideology, see Miriam Dobson, Khrushchev's Cold Summer: Gulag Returnees, Crime, and the Fate of Reform after Stalin (Ithaca, N.Y., 2011). 
These aspirations produced quite awful results in many cases, but the solid (and often well-deserved) critique of Third World nationalisms and their derivative discourses has perhaps overshadowed our understanding of the centrality of notions of catching up in twentieth-century nationalisms. A balanced view of the twentieth century should acknowledge the states' achievements in human development alongside the critique of their dictatorial tendencies.

I come to this from my study of Central Asia in the era of the Russian Revolution. ${ }^{58}$ The collapse of the Russian autocracy in the midst of a world war opened up new possibilities for all sorts of groups. Nationalizing elites saw in the revolution an opportunity for their societies to achieve the dignity that colonial conquest had denied them. This seemed to require the same kinds of power that "advanced" societies already possessed. For them, the revolution was a postcolonial moment that would undo the work of colonialism. Russian settlers sought to preserve their privileges and, as Marco Buttino and others have shown, used soviets (pace Arendt as quoted by Andrew) primarily to dispossess the natives of their land and food supplies..$^{59}$ Eventually, the Soviet state imposed its version of socialism, which had little space for anticolonialism as it had been imagined in the years of the revolution. But the Soviet period also saw massive transformations in the mobilization of populations, the productivization of space, the crystallization of national consciousness, and so on. It accomplished, albeit on its own terms, many of the tasks that many developmentalist national states have aspired to.

Manu Goswami: During the 1990s (with some earlier exceptions), historians of colonial India elaborated a conceptually sophisticated and widely influential literature on colonial governmentality. ${ }^{60}$ This literature was more or less explicitly oriented by the work of Foucault. It generated profound insights about the interlock between colonial epistemologies and modes of rule and the proliferation of techniques of disciplinary power. And it also helped underscore the tragic continuities, as Elizabeth Thompson suggests, between colonial and postcolonial forms of power and state domination. But this literature also carried the limits of Foucault's untenably static, undifferentiated conception of modernity, one that understood modern subjectivity exclusively in terms of instrumental rationality, scanted the transformative and universalist possibilities of popular struggles, and bracketed questions of political economy. Ironically, some of the best insights of the early subaltern studies school about insurgent political practice were jettisoned. My own prior work sought to overcome some of the impasses generated by this literature through an account of the spatial and infrastructural logics of colonial state power and the relational dynamic between the lived experience of colonial capitalism and the forging of historically novel popular conceptions of a national space and

${ }^{58}$ Adeeb Khalid, Making Uzbekistan: Nation, Empire, and Revolution in the Early USSR (Ithaca, N.Y., 2015).

${ }^{59}$ Marco Buttino, La rivoluzione capovolta: L'Asia centrale tra il crollo dell'impero zarista e la formazione dell'URSS (Naples, 2003).

${ }^{60}$ Bernard S. Cohn, Colonialism and Its Forms of Knowledge: The British in India (Princeton, N.J., 1996); Partha Chatterjee, The Nation and Its Fragments: Colonial and Postcolonial Histories (Princeton, N.J., 1993); Dipesh Chakrabarty, Habitations of Modernity: Essays in the Wake of Subaltern Studies (Chicago, 2002); Gyan Prakash, Another Reason: Science and the Imagination of Modern India (Princeton, N.J., 1999); David Scott, "Colonial Governmentality," Social Text 43 (Autumn 1995): 191-220. See also Timothy Mitchell ed., Questions of Modernity (Minneapolis, 2000). 
national economy. ${ }^{61}$ Among the more promising developments in histories of twentiethcentury India is the renascence of political, intellectual, and institutional histories attentive to what Andrew Zimmerman, following Arendt, calls the creative politics of insurgent peoples amid large-scale socioeconomic shifts. ${ }^{62}$ How this emergent literature will reorient and recast conventional narratives of India's twentieth century is, as yet, not entirely clear. But nationalism and the nation-state are no longer the principal horizons of inquiry. Instead, the lineages and practices of democracy and capitalism are explicit objects of critical scholarship.

AHR Editor: I am pleased that Manu has injected "subaltern studies" into the discussion, for whatever one may think of this orientation, it certainly should help us address some of the questions raised by the last few comments. When we try to look beyond or beneath the new "techniques of power" of the twentieth century, as all-pervasive as they appear, our favored narratives frequently come up against an impasse. Many of you have gestured to the need to explore in new ways the dynamics of resistance and liberation that remain possible within the interstices of the growth of the state, surveillance, technology, and the biopolitical that together seem to corral twentieth-century subjectivities. Gabrielle alludes to the "cosmopolitan commons"; Andrew and others (myself included, I confess) remain interested in what was once called "working-class self-activity"; Anna, as I take it, seeks to locate new forms of "resistance, insurgency, protest, and ... critique ... outside of [the] dominant cultural paradigms" of bourgeois individualism; and Manu inquires into "the creative politics of insurgent peoples."

So, that brings me to my next question: What forms of "creative politics of insurgent peoples" did the emergent conditions of the twentieth century make possible? How have these creative politics shifted over time and place? And, most of all, what kind of subjectivities do they presume? As Anna puts it, how can we retain an emphasis on the historical agency of individuals without (a) giving up on the concept of power, and/or (b) giving in to a predetermined form of subjectivity?

Andrew Zimmerman: I would start by turning Alex's excellent question around: Not "What forms of 'creative politics of insurgent peoples' did the emergent conditions of the twentieth century make possible?" but rather "What forms of twentieth-century power did 'the creative politics of insurgent peoples' make possible?" That is, how have various types of state, capital, and institutionalized (e.g., university) knowledge constituted themselves by appropriating varieties of plebeian practices, including politics? Are the forms of knowledge and power peculiar to the twentieth century (Fordism and post-Fordism/neoliberalism, state communism, fascism, the welfare state, the militarycentered research university, the culture industry, etc.) unique responses to an everpresent threat of democracy against hierarchy, or are they responses to new and

${ }^{61}$ Manu Goswami, Producing India: From Colonial Economy to National Space (Chicago, 2004); Goswami, "Rethinking the Modular Nation Form: Toward a Sociohistorical Conception of Nationalism," Comparative Studies in Society and History 44, no. 4 (2002): 770-799.

62 Partha Chatterjee, Lineages of Political Society: Studies in Postcolonial Democracy (New York, 2011); Nivedita Menon, Recovering Subversion: Feminist Politics beyond the Law (Urbana, Ill., 2004); Anupama Rao, The Caste Question: Dalits and the Politics of Modern India (Berkeley, Calif., 2009); Kalyan Sanyal, Rethinking Capitalist Development: Primitive Accumulation, Governmentality, and PostColonial Capitalism (London, 2007). 
uniquely twentieth-century forms of insurgent, plebeian politics? Here we can follow the work of Mario Tronti and others working in the tradition of Operaismo. ${ }^{63}$

How, for example, in Elizabeth's case, did the police states that appeared in the interwar Middle East borrow from the specific forms of plebeian politics they emerged to suppress? How has this dialectic continued since the new round of uprisings in the Arab Spring? Did the technopolitics of Namibian miners that Gabrielle discusses reflect a prior technopolitics of state and capital, or did state and capital draw its technopolitics (including the workers' knowledge of how to mine, how to survive mining) from these workers? The post-totalitarian models of state power that Jonathan discusses suggest similar processes: a Gestapo built from, and not just eliciting, the mutual recriminations of populations; a Stasi that does not simply observe, but is itself an appropriation (sometimes through physical imprisonment) of "the lives of others." 64 Or in the case Adeeb discusses, Soviet power emerges in Central Asia as a kind of crossproduct of the entitlement of Russian settlers and the political and economic aspirations of national elites and populations. I agree with Anna that we need to reconsider agency to grasp power, not from the perspective of its elite appropriators, but rather from those who produce it in the first place. I agree with Manu that subaltern studies, above all as practiced by Ranajit Guha (and inspired by-perhaps even appropriating-the peasant insurgencies going on around him), remains a very good place to start.

Such a reversal might prompt a reperiodizing of the twentieth century around waves of popular insurgency rather than institutional maneuvers by state, capital, university, and other institutional formations. Just to take one example from a text I have been thinking about a lot lately, should we structure a history of the twentieth-century Global South (or at least the twentieth-century U.S. South) around what Clyde Woods calls "blues epistemology" rather than around the plantation complex? ${ }^{65}$ This would mean privileging the forms of worker political, economic, and cultural self-organization that the plantation, from Atlantic slavery to mass incarceration, has not merely oppressed, but lived from, vampire-like. ${ }^{66}$ A standard objection to such a bottom-up account is that it ignores power, the responsibility of those "in" power for various forms of oppression. I would say the top-down account, however, ignores a more important form of power, which is the always-present power of the popular classes to, as the Wobblies sang, "dump the bosses off your back."

Jonathan Zatlin: I really enjoyed Andrew's reversal of Alex's question. Turning Alex's causality on its head-or rather, setting it back on its feet, as Marx did with Hegel's dialectic_-opens up creative avenues for historical inquiry. But as important as Alex's question and Andrew's inversion of it are, I want to draw attention to the ground

${ }^{63}$ For a classic statement, see Mario Tronti, "Lenin in England,” https://www.marxists.org/reference/ subject/philosophy/works/it/tronti.htm, originally published as "Lenin in Inghilterra," Classe operaia, no. 1 (January 1964): 1, 18-20. For a recent assessment, see Tronti, "Our Operaismo," New Left Review, no. 73 (January-February 2012): 119-139.

${ }^{64}$ Das Leben der Anderen (The Lives of Others), dir. Florian Henckel von Donnersmarck (DVD, Munich: Buena Vista Home Entertainment, 2006).

${ }^{65}$ Clyde Woods, Development Arrested: The Blues and Plantation Power in the Mississippi Delta (London, 1998).

${ }^{66}$ Loïc Wacquant, "From Slavery to Mass Incarceration: Rethinking the 'Race Question' in the US," New Left Review 13 (January-February 2002): 41-60. 
on which they stand-to their assumptions about writing the history of the twentieth century.

First, no matter which direction the causality runs, emphasizing "the creative politics of insurgent peoples" depends on resuscitating the two unitary subjects of liberal political fantasy: a powerful state and a disempowered people. To paraphrase Horkheimer, who was himself borrowing from Wittgenstein, whoever wants to speak about defiance cannot remain silent about dictatorship. ${ }^{67}$ Even when expressed as a dialectic, however, this dichotomy is as conceptually impoverished as it is empirically wrong. To give an example that illustrates some of its pitfalls: The courageous protesters who brought about the collapse of European communism in 1989 insisted they were the "people" that the "People's Democracies" claimed to represent. But the "people" is an imagined community, one the protesters understood as the mirror opposite of the totalizing states they opposed. It is also a hypostatization that has no structure or permanence. Within a short time, the social solidarity created by decades of repression in Poland, East Germany, Czechoslovakia, Bulgaria, Romania, and Yugoslavia gave way to a cacophony of competing political, economic, and cultural interests.

Second, as I argued in the last answer, this binary construct not only flirts with ideological obfuscation, but also focuses the historian's gaze on government to the exclusion of economic activity, cultural production, and social relations. At least when it comes to commerce, it's worth remembering that the forces of need and greed always find their way around state-imposed obstacles. In the twentieth century, for example, new forms of transnational trade emerged that sidestepped the most imposing techniques of state control, from smuggling in the Soviet Bloc to the drug trade in the Americas. To be clear, I'm not proposing we expand the "state/people" dichotomy by adding "economy" to the mix; turning to trinitarian formulas won't rescue this kind of political geometry. On the contrary, the dispersal of power in twentieth-century societies requires a suitably nuanced analytical approach that has-as Andrew suggests-its feet firmly planted on local ground.

Third, focusing on "the creative politics of insurgent peoples" forces historical causality into an emancipatory ambit. That is, it subsumes the task of writing history into the work of repairing the world. But because equating insurgency with agency is both a political statement and a narrative preference, I don't think we'd find a consensus for this position in our post-historicist profession.

At the same time, valorizing the history of "insurgent peoples" holds out the hope of uncovering repressed histories by linking agency with defiance. As a historical category, defiance is a rich topic (and one that has received much attention, I think, because of that most twentieth-century of experiences: genocide). Microhistorians from Carlo Ginsburg to Alf Lüdtke have placed efforts to defend individual or group autonomy from encroachment by religious, state, or commercial power at the heart of their analysis. Whether it is the refractory conduct of difficult personalities, such as Ginsburg's heretical hero Menocchio, the more organized noncompliance of Lüdtke's fac-

${ }^{67}$ Max Horkheimer's dictum "Wer aber vom Kapitalismus nicht reden will, sollte auch vom Faschismus schweigen" ("Whoever does not wish to speak of capitalism should also be silent about fascism") seems a play on the famous last sentence of Ludwig Wittgenstein's 1922 classic Tractatus Logico-Philosophicus: "Wovon man nicht sprechen kann, darüber muss man schweigen" ("Whereof one cannot speak, thereof must one be silent"). See Horkheimer, "Die Juden und Europa," Zeitschrift für Sozialforschung 8, no. 1-2 (1939): 115-137, here 115. 
tory workers under Nazi rule, or even the contumacious peasants of James C. Scott's books, analysis of social recalcitrance promises insights into the constellation of social forces that shape individual behavior as well as the individual behavior that disrupts the social norms that assign meaning to our actions. ${ }^{68}$ It is the reason that Harriet Tubman has pushed Andrew Jackson to the back of the buck.

But the difficulty with defiance is that the defiant are not always the heroes of history. Sometimes they are its villains. After all, the Nazis of "the first hour" defied a state - the Weimar Republic — that they viewed not merely as oppressive but also as foreign imposition. Yet there was nothing emancipatory about the Nazis, unless you believe that their goal of liberating the world of Jews was a gruesome distortion of the Enlightenment project.

In the U.S., moreover, defiance has been co-opted by the very authorities who should elicit the greatest resistance. On the one hand, the American Psychiatric Association pathologizes recalcitrant behavior as "Oppositional Defiant Disorder" to facilitate the efforts of law enforcement to identify, healthcare workers to rectify, and insurance companies to circumscribe liability for noncompliant behavior. On the other hand, heroic insubordination is sold as a palliative in books, on the screen, in politics, and on management floors, presumably as compensation for the very real and personal defeats that life brings. But socially acceptable defiance has become both an autonomous category of political analysis and an organizing narrative for cultural production not simply because it provides a clear and comforting explanation for a more complex causality, but also because it resonates with the founding mythology of the American state. It is the reason that American politicians mindlessly inveigh against the "state" in one breath and apostrophize the "people" in the next. It is also the reason that grounding historical analysis in "cultural systems and social circumstances," as Anna puts it, is so important. For without analyzing the ground on which we stand, there is no way to identify what has been turned on its head or which end is up.

Gabrielle Hecht: The Apartheid Museum in Johannesburg, South Africa, features a wall covered with some 150 plaques, each corresponding to a law legitimating discrimination and segregation. When you first confront this display, craning your neck to read the uppermost inscriptions, you feel the overwhelming power of the apartheid stateits ruthlessness, its meticulousness, its relentlessness. But as you continue to stare, taking in the dates and titles of each provision, you realize that the list also represents "the creative politics of insurgent peoples"- their determination, their imagination, their relentlessness. The wall narrates how, over time, the state turned to increasingly specific (and occasionally absurd) legitimations of violence, precisely because people found ways to resist, circumvent, and just plain refuse compliance. This, for me, embodies the dynamics that Andrew and Jonathan invoke in their responses: power as a messy, ever-

${ }^{68}$ Carlo Ginzburg, The Cheese and the Worms: The Cosmos of a Sixteenth-Century Miller (Baltimore, 1980); Alf Lüdtke, "Cash, Coffee-Breaks, Horseplay: Eigensinn and Politics among Factory Workers in Germany circa 1900," in Michael Hanagan and Charles Stephenson, eds., Confrontation, Class Consciousness, and the Labor Process: Studies in Proletarian Class Formation (Westport, Conn., 1986), 65-95; Lüdtke, "What Happened to the 'Fiery Red Glow'? Workers' Experiences and German Fascism," in Lüdtke, ed., The History of Everyday Life: Reconstructing Historical Experiences and Ways of Life, trans. William Templer (Princeton, N.J., 1995), 198-251; James C. Scott, Weapons of the Weak: Everyday Forms of Peasant Resistance (New Haven, Conn., 1985). 
changing outcome of struggle and structure. Of course these laws are instruments of power, quintessentially so, but they also reflect and respond to economic activity (from large-scale industry to smuggling), land, liquor, sex and love, urinating and defecating ... and everywhere, always, race and its classifications. Yet laws fail to contain; there is always excess; and in that excess we locate the complex multidirectionality of power.

But I'd like to pivot away from the languages of power, and back toward its stuff. The twentieth century saw massive scalar shifts in the rearrangement of earthly materials - shifts that many today gloss under the sign of the Anthropocene. Of course these shifts began before the twentieth century: there's (hyper)active debate about the origins of the Anthropocene (nineteenth-century industrialization? sixteenth-century Columbian Exchange?); there's outrage at the silences engendered by the term itself, not to mention its claims to novelty; and there are a proliferation of proposals for alternative designations (the Capitalocene?) that would better signal historical power dynamics. ${ }^{69}$ But there can be little doubt that the twentieth century saw the consolidation and magnification of the biological, geological, and atmospheric transformation of our planet and our bodies. There has certainly been "creative insurgence" in response to all this, from environmental movements and other sources. But it's fair to say that we have barely begun to come to grips with the conditions of political possibility that propel and respond to these transformations. South African courts recently declared that former mineworkers, living with silicosis and tuberculosis after decades in the mines (during and after apartheid), could move forward with a class-action lawsuit against mining companies. Tens of thousands of workers are potentially involved. How do we understand such lawsuits as forms of collective politics? As performances of subjectivity? As modes of historical accounting? These are some of questions that form the legacy of the twentieth century.

Anna Krylova: I share Jonathan's concern about conceptual pitfalls that the project of looking for historical agency in the midst of historical circumstances not of our choosing, to paraphrase Marx, entails. ${ }^{70}$ The difficulty indeed arises the moment one invokes the concept of a "structure" or a "system" (be it state, social, economic, institutional, cultural, discursive, linguistic), to which one ascribes a logic of its own and into which one inserts the historical subject. The more recent concept of "power" encompasses (at least in theory) all of the above: it claims a variegated complexity, totality, and, as I have argued earlier, further encourages a treatment of historical subjectivity as an effect of historical circumstances. Rescuing the subject from the structure/power predicament, so to speak, has been a persistent theoretical and ethical problem. ${ }^{71}$

I also agree that what Jonathan calls the defiant subject-historians' standard device to remedy the effacement of historical agency in studies inspired by structuralist and poststructuralist analytics-falls short of giving back to the historical subject its role as an agent of history. Here, of course, much depends on how one defines and theo-

${ }^{69}$ For excellent introductions and challenges to debates about the Anthropocene among historians, see Christophe Bonneuil and Jean-Baptiste Fressoz, The Shock of the Anthropocene: The Earth, History, and Us (London, 2015); and Julia Adeney Thomas, "History and Biology in the Anthropocene: Problems of Scale, Problems of Value," American Historical Review 119, no. 5 (December 2014): 1587-1607.

${ }^{70}$ Karl Marx, The Eighteenth Brumaire of Louis Bonaparte (New York, 1963), 15.

${ }^{71}$ Ronald Grigor Suny, "Back and Beyond: Reversing the Cultural Turn?," American Historical Review 107, no. 5 (December 2002): 1476-1499. 
rizes agency - the question that I am presently grappling with. In its most recent renditions informed by Lacanian poststructuralist psychoanalytic theory, the defiant subject has been reconfigured as transgressive or subversive. My problem with this construct (which I articulate elsewhere) is that the defiant/transgressive subject does not presuppose a beyond, that is, an actual articulable position situated outside the presumed totality of a system of domination. ${ }^{72}$ Thus, the defiant subject in our studies defies (or disrupts) the social norms but does not remove them, and does not attempt to articulate an alternative. Likewise, the transgressive subject, as conceptualized by Joan Scott in The Fantasy of Feminist History, transgresses the restraints of the norm, thanks to his/ her psyche's unconscious desires and urges, but still has no other ground to come back to, except the one being transgressed. ${ }^{73}$

However, I believe that the subject that Alex and Andrew want us to consider (and I am on board with this agenda) is different from the defiant/transgressive one. I take it that in "creative politics of insurgent peoples," "creative" is as important as "insurgent." What is at stake in Alex's question and Andrew's reversal of it is the authorship of the very terms and forms of political struggles and, consequently, undergirding notions of political subjectivity and social justice. The creative/insurgent subject implicit in their questions does not simply disrupt. It authors alternatives (even if those alternatives are later appropriated and deprived of their radical content); it inhabits and embodies an articulable beyond; it exposes the falsity of the totality that a dominant regime of signification and domination claims to itself; and in Andrew's reconfigured question, we are invited to consider granting "insurgent peoples" history-making powers.

Twentieth-century Russian and European history contains numerous examples that help explicate the difference between these two forms of being a subject and relating to dominant regimes of power. One can consider, for example, the demoralized worker of Stalinist industrialization, resisting state-imposed and ever more intense tempos of production and exploitation, on the one hand, and the self-organizing worker of the 1905 and 1917 Russian Revolutions, forming workers' councils (brought up already by Andrew), on the other. The former (explored by Andrew Sloin in his recent article on deep socioeconomic mechanisms of working-class Soviet antisemitism) relies on antisemitic explanatory scenarios and engages in violence against Jewish workers. The latter introduces and (dare we say) authors a new mass form of radical governance, which caught contemporaries by surprise and was nearly immediately theorized by Lenin as the embodiment of the proletarian creative energy to make history and to offer new forms of political and administrative governance to the world. ${ }^{74}$

I do not advocate that we follow the Bolshevik leader and begin to idealize the Russian proletariat. I would also caution us against narrating the history of the workers'

72 Anna Krylova, "Gender Binary and the Limits of Poststructuralist Method," Gender and History 28, no. 2 (2016): 307-323.

${ }^{73}$ Joan Wallach Scott, The Fantasy of Feminist History (Durham, N.C., 2011). The concepts of unstable, mutable, and conflicted identity and transgressive subjectivity played a cardinal role in the making of gender history, where scholars drew on now-classic works: Judith Butler, Gender Trouble: Feminism and the Subversion of Identity (New York, 1990); Elizabeth Grosz, Sexual Subversions: Three French Feminists (Boston, 1989); Denise Riley, “Am I That Name?” Feminism and the Category of "Women” in History (London, 1988); Slavoj Žižek, The Plague of Fantasies (London, 1997).

${ }^{74}$ Andrew Sloin, "Theorizing Soviet Antisemitism: Value, Crisis, and Stalinist 'Modernity," Critical Historical Studies 3, no. 2 (2016): 1-33; Laura Engelstein, Moscow, 1905: Working-Class Organization and Political Conflict (Stanford, Calif., 1982). 
councils by relying on nineteenth-century liberal ideals of "independent will," "volition," "self-determination," which Walter Johnson critiqued so devastatingly and persuasively in his "On Agency." 75 But together with Alex and Andrew, I do want to suggest that to begin to acknowledge and account for the radically different ways of conducting oneself in history that the two examples foreground is a productive starting point to rethink, theorize, and reclaim the category of agency for the historical profession. At the very least, we will be forced to begin to detail what we mean when we say "agency." The notion of the creative/resurgent subject as discussed above undoubtedly grants our historical subjects a possibility to gain a critical distance in relation to power regimes that claim them as their subjects. Are we comfortable granting this skill to our historical actors, and how can we justify this assertion theoretically? After all, why should we not grant our historical subjects what we grant ourselves?

It seems to me that one way to move forward is to question the very way we talk about "agency," that is, as an a priori property that we can grant or deny. A better way that this conversation suggests and that I have been thinking about is to view agency not as an a priori property but as what I will tentatively call here a historical condition. Then, the question that we might want to pose would be: Under what historical conditions does a historical subject become an agent who gains a critical perspective, that is, recognizes that the totality of a dominant regime is only claimed and is never there?

Elizabeth F. Thompson: I write from Beirut, where there is no strong government, and where micro-movements proliferate to protect parks and open schools for Syrian refugees, but where an oligarchy of rival elites assures immobility in governance. Next door is the country I have long studied, Syria. In 2011 and beyond, citizens' committees mushroomed to organize local resistance and community support as nonviolent protest was co-opted by the state and foreign-fed militias into civil war. The central problem for much of the globe in the twentieth century has been the lack of a political arena, an absence of sovereignty-or to put it another way, how to live in a society where the strings of power extend far beyond one's reach, in imperial capitals of Europe and North America. Only later in the century did Europeans and North Americans recognize they faced a similar dispersion of power beyond the reach of a local, sovereign political arena they could hope to conquer.

Alex has posed a huge question that cannot be properly answered in a few paragraphs. To start, I embrace Anna's project of distinguishing the "defiant subject" from the "creative insurgent" as a way of thinking about how and where Arab people have asserted agency against these global processes. I will also briefly respond to Andrew's query about how the Arab Spring continued a dialectic of strategic borrowing between the state and non-state movements.

Over the course of the twentieth century, Arab political strategies at one time expressed a kind of creative politics, only to fall into pointless defiance, and vice versa. An example: By the turn of the century, opposition leaders in the Middle East began to appeal to parliaments and public opinion in imperial metropoles: they sent petitions and delegations to protest the policies of colonial ministries and their lackeys in Cairo, Constantinople, Beirut, Damascus, Tunis, etc. In the 1919 Egyptian Revolution, peti-

75 Walter Johnson, “On Agency,” Journal of Social History 37, no. 1 (2003): 113-124; Lynn M. Thomas, "Historicising Agency," Gender and History 28, no. 2 (2016): 324-339. 
tioning embassies became a new ritual of protest, as well as sending flurries of telegrams to the U.S. Congress. Syrians seeking independence adopted these same tactics. Both failed. Palestinian Arabs tried the same, to little effect. But they and Algerians learned a new way of gaining imperial attention: violence. It is quite clear they learned this from a rival trend: Eastern European anarchists. ${ }^{76}$ Armenians adopted terror to attract international attention by taking over the central bank in Istanbul before World War I. Zionists brought these techniques to bear in ousting Britain from Palestine in the 1940s. The Algerians adopted it in the famous Battle of Algiers, which finally brought the UN in to pressure France. But the Palestinian PLO failed in a similar use of the tactic. Arafat brought both a gun and olive branch when he finally was permitted to speak at the UN in 1974. Palestinian terror, however, had by then devolved into what Anna would call a pointless politics of defiance without a constructive alternative-for reasons too complex to explain here.

The Arab Spring was heir to this repertoire. It appealed at first, nonviolently, to the world media. Taking over a central square, waving signs, staging events, all were designed to draw international pressure on the local dictator-in Tunis, Cairo, the various cities of Syria. They drew both on Gene Sharp's modular modes of protest and on local micropolitics of mutual aid and resistance. They also drew on a long history of "youth" resistance in the Middle East, which emerged in the 1920s as a cultural protest against politicians who collaborated with colonial powers. ${ }^{77}$ (In Baghdad in 1959, a million people camped in city parks and staged a parade, where they tossed flowers and sang folk songs about peace-in praise of the new government that had overthrown the monarchy the previous July. Descriptions of it remind one of Woodstock!) So too in Cairo a stage filled with musicians, comedians, poets, and so on. But the Arab Spring hitched too much on the old repertoire of international petitioning. The young people and their parents who had lived under dictatorships that permitted little political organizing had little more than slogans about returning to constitutional government. There was no civil organization. Only in Tunis did the labor union still wield autonomous power.

Here, finally, I must place the rise of Islamism in this context. It qualifies, I believe, as a creative insurgency. When Arabs were let down at the 1919 Paris Peace Conference, and left in the hands of colonial powers despite their massive service to the Entente during the war, Islamism grew as an alternative to European liberalism. Excluded from the family of nations and rights under the international law promoted by Woodrow Wilson, local political leaders and professionals turned to the project of creating a separate justice, distinct from the so-called international liberal project controlled by Europe for European benefit. From the 1920s onward, Islamists built not only an ideology, but a movement that perpetuated itself through community workbuilding mosques, schools, clinics, etc. Some branches of the movement, however, turned to violence under the same influences that Palestinian movements did. It was also co-opted by the financial help of governments, turned into a puppet of regional rivalries. And so entered the Arab Spring as a conflicted actor.

76 Thompson, Justice Interrupted, chap. 9. See also the memoirs of a Polish-born Israeli leader of a terror group: Menachem Begin, The Revolt, revised ed. (New York, 1978); and of a Palestinian leader in the PLO: Abu Iyad, My Home, My Land: A Narrative of the Palestinian Struggle, trans. Linda Butler Koseoglu (New York, 1981). 1973).

77 Thompson, Justice Interrupted, chap. 11; Gene Sharp, The Politics of Nonviolent Action (Boston, 
A final thought about the dialectic of state: dictatorships have co-opted movements of liberation-especially in the mid-twentieth century-through classic methods of corporatism. Labor unions were incorporated into the state; so too were peasant, Islamic, and women's movements. There is a relationship between that phase of corporatism and the proliferation of what we would call defiant movements in the later twentieth century. We live now in a depressing period when faith in creative insurgency is a low ebb, while foreign governments keep pumping weapons into Syria, used to kill Syrians of all political persuasions. Until the killing stops, and it won't stop until outsiders decide to do so, it is difficult to speak of agency. For a while, agency came through walking - on the legs of hundreds of thousands of refugees. But foreigners have put up a new wall-penning Syrians into their war zone. In 1919, Arabs were denied sovereignty and excluded from the family of peoples who would enjoy full human rights. As W. E. B. Du Bois said, the problem of the twentieth century was the problem of the color line. A century later, we are replaying the same process of exclusion and denial of agency.

Adeeb Khalid: I also share Jonathan's discomfort with the juxtaposition of powerful states and disempowered populations that is implied in the question, where agency is to be found in insurgency. But the history of the twentieth century is also the history of consenting populations, whether the consent was manufactured or not, of citizens aligning their egos along particular visions of the social. Nor is all defiance necessarily political. Smuggling, corruption, and informal economies are all ways of bypassing the states without necessarily a political motive. In the Soviet Union, the shadow economy, functioning on the basis of blat, actually allowed the official economy to continue to function. Finally, in valorizing defiance and subversion, we should remember that they can come (and usually come) from the strong and the dominant as much as from the weak and the marginalized. To Jonathan's example of the Nazis during the Weimar, we can add any number of movements throughout the course of the twentieth century of angry stakeholders who felt their control ebbing away and who used all means at their disposal, from violence on down, to wrest control back. (The recent presidential campaign in the U.S. offers a pertinent example from the early twenty-first century.) Anna's insightful comments on the nature of agency point to a way forward in this regard, and I look forward to seeing her ideas fully articulated in the near future.

I also wonder if the focus on (state) power is sufficient to understand all that the twentieth century was about. Women's movements have often operated through and across the instruments of state power, and I do not believe that patriarchy can simply be subsumed into the state. The twentieth century saw many projects of "state feminism" that sought to reorder the place of women in society and took on established forms of patriarchy. They faced backlashes in the name of religion, honor, or tradition. As I write this, my native land (Pakistan) is roiled by controversy over the passage of a Protection of Women Against Violence Bill by the government of Punjab. The mildness of its provisions (women can now file legal complaints against abusive husbands, who may be arrested and prosecuted; women will also have recourse to emergency phone numbers and shelters) did not prevent an outcry from conservative religious groups, who have challenged the legality of the bill and threatened mass mobilization against it. Were that mobilization to succeed, the resulting insurgency would be neither 
very creative nor emancipatory. It will bank on a claim to some sort of authenticity, in this case premised on a peculiarly localized modern reading of Islam. The search for authenticity - whether of nation, culture, or religion - is a key feature of twentieth-century politics. To be sure, it is thoroughly imbricated in relations of power and is often as much a product of fear as of strength. Authenticity is attractive precisely it compensates for the diminution of sovereignty and loss of control over the economy. But the appeal of claims to authenticity cannot be denied.

I am afraid my musings have carried me away from some of our core themes, so I would like to return to Gabrielle's point about turning back to the "stuff" of power. During the twentieth century, the population of our planet increased fourfold (despite the century's unprecedented violence and devastation), we used up large parts of the earth's mineral deposits (fossil fuels in particular), and urban (and slum) life became the lot of most of us. How do we convey the enormity of these changes and their connection to regimes of power (and resistance to it)? These might be key questions for twenty-first-century historians of the twentieth.

Manu Goswami: Given the rich discussion that has unfolded on agency as a historically variable condition, it seems pedantic to point out that the phrase "the creative politics of insurgent peoples" was Andrew Zimmerman's gloss on Hannah Arendt's muchdebated conception of politics. ${ }^{78}$ I referenced his usage to note an affinity between this improvisational and practice-oriented conception of politics and recent efforts by historians and historically minded social scientists to rethink the political contours of India's twentieth century. Put broadly, there is growing empirical and conceptual attention to the variegation of popular politics across and within specific historical conjunctures, spanning universalistic movements that emerged in late colonial India-for example, the abolition of indentured labor, the emancipation of Dalit groups, the unexpected internationalist projects incubated by colonial subjects-to ongoing efforts to radicalize political and economic democracy in more recent decades. ${ }^{79}$ There is no single conceptual orientation that organizes this line of inquiry. Yet three aspects of this emergent literature stand out in relation to our wider discussion. First, and most obviously, this emergent literature upends the nominalist schema of periodization that conventionally seizes upon the 1947-1948 moment (the emergence of two nation-states, India and Pakistan) to partition the colonial from the postcolonial era and that has tended to see na-

${ }^{78}$ For distinct readings of Arendt, see Hanna Fenichel Pitkin, The Attack of the Blob: Hannah Arendt's Concept of the Social (Chicago, 1998); Seyla Benhabib, The Reluctant Modernism of Hannah Arendt, new ed. (Lanham, Md., 2003); Patchen Markell, "The Rule of the People: Arendt, Archê, and Democracy," American Political Science Review 100, no. 1 (2006): 1-14.

${ }^{79}$ Rachel Sturman, "Indian Indentured Labor and the History of International Rights Regimes," American Historical Review 119, no. 5 (December 2014): 1439-1465; Mrinalini Sinha, "Premonitions of the Past," Journal of Asian Studies 74, no. 4 (2015): 821-841; Sinha, "Suffragism and Internationalism: The Enfranchisement of British and Indian Women under an Imperial State," Indian Economic and Social History Review 36, no. 4 (1999): 461-484; Rosalind O'Hanlon, Caste, Conflict and Ideology: Mahatma Jotirao Phule and Low Caste Protest in Nineteenth-Century Western India (1985; repr., Cambridge, 2002); Rupa Viswanath, The Pariah Problem: Caste, Religion, and the Social in Modern India (New York, 2014); Maia Ramnath, Haj to Utopia: How the Ghadar Movement Charted Global Radicalism and Attempted to Overthrow the British Empire (Berkeley, Calif., 2011); Manu Goswami, "Imaginary Futures and Colonial Internationalisms," American Historical Review 117, no. 5 (December 2012): 14611485; Michael Levien, “The Politics of Dispossession: Theorizing India's 'Land Wars," Politics and Society 41 , no. 3 (2013): 351-394. 
tionalism as exhaustive of the political. Second, India's twentieth century is rendered less as a fixed, objective datum than as a necessarily relational historiographical project, inextricably part of wider regional, trans-imperial, and global formations. And, finally, what seems especially generative is an emphasis on the interplay between shifting conceptions of the possible (a nodal condition of politics as such) and specific historical conjunctures. From this vantage, political actions can create, in a kind of "regulated improvisation" (to use Bourdieu's parsing of the structure/agency question), unanticipated historical conjunctures, and they can spawn, not just passively reflect, new "horizons of expectations." 80

The joining of collective politics with historical temporality is an embedded artifact of the global twentieth century. It is not, in other words, just a timeless methodological conundrum. Even the constellation of terms that we use to distinguish historical time from mere chronology, terms such as conjuncture, crisis, revolution, event, were born and borne across world regions (and linguistic zones) by twentieth-century anti-systemic political and social movements. It is not surprising, then, that so many conceptual reckonings with the twentieth century have tended to foreground the question of the political. I am thinking here of the macrohistorical and historical-sociological vein of Eric Hobsbawm's Age of Extremes and Giovanni Arrighi's The Long Twentieth Century, on the one hand, and the explicitly philosophical and partisan diagnostic offered by Susan Buck-Morss's Dreamworld and Catastrophe and Alain Badiou's The Century, on the other. ${ }^{81}$ Considered together, these works illustrate why we must grapple, in tandem, with both the sheer political dramaturgy and the large-scale systemic continuities that characterize the global twentieth century. (They also highlight, along the way, the heterogeneity of historical materialist traditions, long caricatured as a monolithic economism.) From this vantage, Gabrielle's vivid injunction to attend not only to "the languages of power" but "its stuff" has special urgency. In the age of the Capitalocene, any effort to rethink "the political" for a specific world region and conjuncture must pay equal heed to entrenched inequalities and persistent hegemonies.

AHR Editor: To close the conversation, let's return to the question we began with, and that Manu has pointed us back to: narrative and temporality. So far, we have considered the nature of the "moral narratives" available to historians of the twentieth century, the novel techniques of political domination and social power deployed by states and elites, and the forms of "creative" politics from below that have pushed forward

${ }^{80}$ Pierre Bourdieu, Outline of a Theory of Practice (Cambridge, 1977), 78; Reinhart Koselleck, “'Space of Experience' and 'Horizon of Expectation': Two Historical Categories," in Koselleck, Futures Past: On the Semantics of Historical Time, trans. Keith Tribe (Stanford, Calif., 1985), 267-288.

${ }^{81}$ Giovanni Arrighi, The Long Twentieth Century: Money, Power, and the Origins of Our Times (London, 1994); Hobsbawm, The Age of Extremes; Buck-Morss, Dreamworld and Catastrophe; Alain Badiou, The Century, trans. Alberto Toscano (Cambridge, 2007). Arrighi's long twentieth century does begin, of course, in the fourteenth century. But its explanatory schema-how recurrent crises of accumulation manifest as financialization and, in turn, signal shifts in hegemonic orders-bears the imprimatur of twentieth-century geopolitical struggles associated with the 1930s and 1970s. In this respect, it shares more ground than it might appear, at first glance, with Hobsbawm's famously "short" twentieth century. Both Buck-Morss and Badiou emphasize the modes of self-reflexivity they see as constitutive of the twentieth century as a philosophical category and the expansive, collective, and long-run temporal horizons bequeathed by twentieth-century modernisms. Only Arrighi and Badiou substantively reckon with decolonization (and indeed regions beyond Europe) as a structuring event of the twentieth century, an astonishing absence that only underlines the perspicacity of Maier's essay. 
new possibilities and subjectivities. Yet, as I think Jonathan's last answer implies, these discourses tend to presume a linear, even progressive, narrative of history, whether Marxist, liberal, or postmodern. But what if "time's arrow" fails to move in a straight line? What if the illusion that it does so is merely an artifact of the conceptual tools we use to impose order on the recent past, as Manu points out? What if the true legacy of the twentieth century is, for example, the ever-steeper declining slope of the downside of the Anthropocene, as Gabrielle and Adeeb hint? What if our current epoch, shaped ineluctably by twentieth-century developments, represents the decomposition of sovereignty, as Elizabeth notes? What if most forms of political expression and action tend to the mimetic rather than the dialectical, as proposed by Andrew?

These thoughts are prompted, in part, by a moving performance of Lorraine Hansberry's 1958 play $A$ Raisin in the Sun that I attended last year in Johannesburg. In a line that surely must have struck home for an increasingly cynical post-apartheid South African audience, the protagonist skeptically asks her anticolonial African suitor about the future of an independent continent. "What about all the crooks and thieves and just plain idiots who will come into power and steal and plunder the same as beforeonly now they will be black and do it in the name of the new Independence ... ? ... Don't you see there isn't any real progress," she concludes, "there is only one large circle that we march in, around and around, each of us with our own little picture in front of us-our own little mirage that we think is the future." To this, her idealistic African paramour (remember, this was 1958, the eve of Ghanaian independence) replies, "It isn't a circle-it is simply a long line-as in geometry, you know, one that reaches into infinity. And because we cannot see the end-we also cannot see how it changes." 82

To formulate this as a discrete question: Does the twentieth century lend itself to a linear historical narrative with an uncertain end, a circular march driven by the chasing of a mirage, or some other historical geometry altogether?

Gabrielle Hecht: I'd suggest that the twentieth century-both as a time period and as a historiographic frame-teaches us about the insufficiencies of geometric metaphors. Don't get me wrong: geometry is great. It helps us describe shapes and patterns; it enables us to measure and navigate; it gives us tools for projecting one set of dimensions onto another. As historians, we engage in all these practices, and secretly enjoy the explanatory distillations that they afford.

Yet the prolific historiographers of the twentieth century have identified variations, disjunctures, and inequalities far more intricate even than the shapes analyzed by, say, differential geometry (which deals with curved space). This conversation has offered a wide range of such complexities; for example, as Adeeb noted most succinctly in the last round, some insurgencies are emancipatory, while others crave the yoke of authenticity. In explaining such dynamics, lines and circles just don't cut it. But refusing the premises of geometric thinking is tantamount to defying the epistemological order instantiated during the twentieth century in many parts of the world, an order in which state power was predicated upon-or at least legitimated by — the predictive promises of statistics and other mathematical regularities. As historians, we've observed how such order has functioned as both resource and target for insurgency; to each other, we

${ }^{82}$ Lorraine Hansberry, A Raisin in the Sun (New York, 1958), 133-134. 
rail against the heresies of simplification, explain that linear time is a cultural product, delight in fine-grained analysis filled with exceptions. But when we venture into other circles, we crash into the expectations imposed by a twentieth-century epistemological order that privileges rules and predictions, vectors and direct causality. When asked by students or journalists to foretell the future, most of us hem and haw. "It's complicated," we sigh. "History is not a predictive science," we sniff, with total conviction but also some embarrassment.

What other metaphors can twentieth-century history put at our disposal? The burgeoning literature on the Anthropocene has drawn our attention to geology, a quintessentially historical science. Sedimentation (already a favorite among theory-heads) acquires materiality, and new meanings. Stratigraphic layers anchor continuity, while fault lines propel discussions of rupture. ${ }^{83}$ And then there's the endpoint of so much geological practice: extraction, which explodes and juxtaposes temporalities, recycling the remains of organisms dead for millennia into the fuel of contemporary need and greed, propelling planetary exhaustion in the rush toward the horizons of expectation set during the twentieth century. How can the exponential scaling-up of physical sedimentation and extraction (and their associated wastes and toxins) help us frame and explain the massive scaling-up of processes such as urbanization, migration, and demographic growth (and their associated violence)? These are nonlinear developments, with nonlinear dynamics, causalities, and temporalities. The mathematics that emerges from twentieth-century history is not just one of statistics and aggregates-it's also a mathematics of logarithms and exponents.

Adeeb Khalid: My first thought was to state the obvious: that we can write history any which way we want. I read the prompt in Kashgar, in the Xinjiang Uyghur Autonomous Region of the People's Republic of China, a place the very narrative of whose history is deeply contested between the Chinese state and the bulk of the Uyghur population. Is the city Kashi, part of the Western Regions that have been part of the great Chinese homeland since time immemorial (as the official line goes), or is it Kashgar, a Central Asian oasis city with a Turkic Muslim population and a history connected to the steppe and to the Muslim world? And is its twentieth-century history one of liberation by the Communist Party of China and the Chinese People's Army or one of repeated failed attempts at national statehood? I am sure we can all think of examples of such deeply contested histories from our own areas of expertise, and they encompass some fundamental features of history-writing.

Answering the question in the spirit in which it was asked-how do we professional historians conceptualize the history of the twentieth century?-is not much easier, since the answer depends not just on the historian but on what aspect of history one is concerned with. After all, the one thing we have all grown less fond of are totalizing grand narratives. The twentieth century was indeed dumb for reasons suggested by Andrew, and among its casualties were notions of linear (or dialectical) progress-not just those entertained on the left but also their conservative counterparts. In the early twentieth century, "backwardness" and the necessity of "catching up" were central concepts for

${ }^{83}$ Douglas Northrop, "Earthquakes on the Edge: Border Spaces and Empire Making along the Eurasian Frontier," lecture to the Eisenberg Institute for Historical Studies, University of Michigan Department of History, September 11, 2014. 
states and intellectuals outside of Europe, producing what we might call a discourse of comparative backwardness. Socialism appealed to many, being it promised a way forward. After World War II, discourses of "development," "green revolution," and the like sought to co-opt the quest to overcome backwardness to the global status quo. They have all passed from the lexicon of the day, and only the all-American (and self-delusionary) search for a "more perfect union" continues to feature in public discourse today.

As I said in my last post, the twentieth century has seen enormous, unprecedented transformations in the natural world. It has also seen the passage of empire and the rise of formal sovereignty, so that today most of the world's people are not formal imperial subjects. Yet the limits of formal sovereignty are all too clear. And the twentieth century has seen greater resources devoted to war than at any time in the past. How do we subsume all of this into a single global pattern for the whole century?

Jonathan Zatlin: Alex has raised an important question, one that has made me wonder, once again, why historians today seem comparatively uninterested in the construction of historical time. We often describe our work as focused on "change over time." In practice, however, we treat this formula not as an equal relation between two variables, but as if controlling for time frees us up to investigate transformation. To judge from recent scholarly publications, historians are more invested in identifying discontinuities than analyzing temporalities. So I find myself wondering why Alex's question is so "timely."

One clue about our preference for change over time is embedded in the displacement of temporal symmetry by temporal succession as the dominant construction of social time. Cyclic time apprehends every new event as a repetition or reenactment of previous occurrences, which imbues it with deeply ahistorical tendencies. To give a contemporary example, traditional (halakhic) Jews often view the Shoah as the recurrence of previous catastrophes, most notably the destruction of the First and Second Temples, the destruction and dispersal of Palestinian Jewry by the Romans, and to a lesser extent the expulsion from Spain and the Khmelnytsky massacres of 1648-1656. On this view, the unique qualities of each catastrophe are of less interest than their similarities. Indeed, whatever the historicity that is lost to cyclic time, the organization of social time as repetition helps mitigate the terror of catastrophic events while generating collective meanings that appear to stand outside time. It is this creation of social meaning through repetition that goes some way toward explaining the gap between history and memory.

In stark contrast, linear time demands that each event be treated as singular and without precedent. As a product of Christian eschatology, it slowly supplanted notions of cyclic time in the West, eventually giving rise to a scientific inquiry focused on temporal succession and a literary genre distinct from chronicles or poetry. Of course, this displacement was incomplete. The cyclic organization of history survived in different forms, surfacing in such places as Hegel's repetition, which Marx coyly apostrophized as tragedy and farce, even if this recurrence remained in service to linear progression. By the end of the nineteenth century, however, the cyclic organization of time was increasingly invoked as a form of resistance to the temporality of "progress." We see glimmers in Nietzsche's declaration of the "death of God" and his notion of eternal recurrence, and in Freud's repetition compulsion, which after 1914 made him doubt the trajectory that ends in therapeutic cure. 
But it required the genocidal rage of the twentieth century to break the promise of progress. The incomplete disenchantment and dechristianization of the Western world has voided developmental time of its redemptive content, yet left us with its teleological form. The unrestrained violence of the twentieth century, together with its Panglossian insistence on progress even in the face of the environmental destruction that Gabrielle mentions, has generated a crisis in the construction of historical time. And yet, popular culture continues to embrace the retrenchment of linear time embedded in Santayana's moralistic construction that "those who cannot remember the past are condemned to repeat it."

To the extent that progressive time is collapsing as an organizing principle, it has freed us up to think more clearly about the history we write. For example, it is increasingly possible to imagine different constructions of historical time as coexisting simultaneously in one place. I keep thinking of Adeeb's idea of "comparative backwardness"- or the generation, through colonial occupation and imperial predation, of developmental time, in which an anxiety over "falling behind" a Western present directs excavation of the past. Similarly, anxieties over historicity draw attention to other disjunctions-between individual and collective psychology and between the participant in and the observer of the past. As Alex suggested, the temporal concepts that informed historical actors are hardly identical to the chronometric assumptions of historical analysts. Moreover, narratological demands impose their own constraints, which are often at odds with the timeliness of the history we wish to recount. I have no answers to this question, but I do hear Marvell's "winged chariot drawing near." My worry is that we have world enough, but not the time.

Anna Krylova: Gabrielle's critique also resonated with me, but I am finding it difficult to navigate through different connotations of the "linear" that our conversation has invoked. I also wonder whether it is paramount or possible to refuse "linear" thinking in all its applications in historical analysis and in our narration of historical constructs such as the "twentieth century."

I am afraid that for the sake of the argument we have ended up with a far too narrow notion of a linear conception of history. The critique that linear thinking averages out and deletes historical complexities, irregularities, and variations presupposes that linear models, by definition, are antithetical to nuanced and contextually grounded analysis. However, this is hardly the case even with the tirelessly critiqued Marxist model, this accepted archetype of linear and progressive thinking about history. Far from antithetical to historical complexities, Marxist linear dialectics as a historical method is not only inclusive of but predicated on the presumption of historical contradictions, cyclical and spiral repetitions, lasting leftovers of the past, irregularities, and farcical recurrences. This is not to say that the Marxist model does not produce gaps and omissions, does not "emplot," and does not moralize (otherwise we would not call it "Marxist"), but this does remind us that we should not make our task of critiquing linear models easier than the task needs to be. Most importantly, the example of linear dialectics seems to underline profound interdependencies of linear, cyclical, spiral, irregular, farcical modeling of history. Far from incompatible, they belong to the same rather complex modern epistemic system, and one cannot give it up by simply rejecting its fragments. In other words, a pursuit of a historical narrative that privileges a study of the cyclical, or the spiral, or the irregular, the variable, the absurd, would still presup- 
pose some concept of the linear. Maybe the challenge that we face is to learn how not to automatically privilege or reject one mode of analysis over another and how to accomplish such a task in a historical narrative of the twentieth century?

This question, I believe, stands particularly acutely in relation to the field of modern Russia as it continues to interrogate the emplotment of the Soviet encounter with socialism into a master narrative of "stagnation" and "collapse" in its "tragic" variation, to borrow from Hayden White's classification of historical-literary genres. ${ }^{84}$ At the level of fundamental aspirations, this still-dominant story equates the Soviet modern project with Bolshevism. Put into practice in the 1930s, during Stalinist industrialization, the Bolshevik socialist alternative, in this account, continued to define Soviet modernity after the war and survived the continuous cycle of ultimately futile revisions and reforms of its original premises. As a result, the story makes the "collapse" and "return" into the imperfect world of capitalism seem inevitable. The need to work out a new set of analytics to approach postwar Soviet socialism also seems unnecessary. ${ }^{85}$

Paradoxically (from the standpoint of the existent critique of linear thinking), it is precisely social changes that, in demographic calculations, form what looks like a linethe dramatic, continuous, and irreversible growth of Soviet urban population between the 1930s and 1970s, for example, that could help historians to escape the story of stagnation and begin to build a more nuanced and uneven historical narrative of Soviet socialism. To clarify, I consider linear developments observable on a relatively short time scale to be rare and exceptional historical occurrences. For this reason, periods that form trajectories of rapid linear growth point to unprecedented and profound social transformations in the lives of historical subjects, which require a close historical analysis and which could hardly fit a narrative of stagnating society. ${ }^{86}$

Andrew Zimmerman: At the end of the twentieth century, a number of thinkers in Europe and the United States-Foucault, Lyotard, Fukuyama, for example-demanded that the left give up a linear temporality aiming toward a more perfect state, 1973).

${ }^{84}$ Hayden White, Metahistory: The Historical Imagination in Nineteenth-Century Europe (Baltimore,

${ }^{85}$ For agenda-setting formulations and narrations of the Soviet experiment that privilege tropes of undergirding continuity (including non-linear) and/or stagnation, see Kotkin, Magnetic Mountain; Stephen Kotkin, Armageddon Averted: The Soviet Collapse, 1970-2000 (Oxford, 2001); Katerina Clark, Petersburg: Crucible of Cultural Revolution (Cambridge, Mass., 1995); David L. Hoffmann, "Was There a 'Great Retreat' from Soviet Socialism? Stalinist Culture Reconsidered," Kritika: Explorations in Russian and Eurasian History 5, no. 4 (2004): 651-674; Hoffmann, Stalinist Values: The Cultural Norms of Soviet Modernity, 1917-1941 (Ithaca, N.Y., 2003).

${ }^{86}$ The paradigm of "uneven development" might work better to capture diverging trajectories of social, economic, political, and cultural change in the Soviet twentieth century and create room for scholarship that parts ways with the master narrative of stagnation and fundamental cultural continuity of the Soviet socialist project. Moshe Lewin, The Gorbachev Phenomenon: A Historical Interpretation (Berkeley, Calif., 1989); Ronald Grigor Suny, "Obituary or Autopsy? Historians Look at Russia/USSR in the Short Twentieth Century," Kritika: Explorations in Russian and Eurasian History 3, no. 2 (2002): 303-319; Susan E. Reid, "Toward a New (Socialist) Realism: The Re-engagement with Western Modernism in the Khrushchev Thaw," in Rosalind P. Blakesley and Susan E. Reid, eds., Russian Art and the West: A Century of Dialogue in Painting, Architecture, and the Decorative Arts (DeKalb, Ill., 2006), 217-239; Benjamin Nathans, "Soviet Rights-Talk in the Post-Stalin Era," in Stefan-Ludwig Hoffmann, ed., Human Rights in the Twentieth Century (Cambridge, 2011), 166-190; Michael David-Fox, Crossing Borders: Modernity, Ideology, and Culture in Russia and the Soviet Union (Pittsburgh, 2015); Alexey Golubev, "Desirable Things of Ogoniok: The Material Face of a Soviet Illustrated Magazine from Stalin to Brezhnev," Soviet and PostSoviet Review 43, no. 2 (2016): 152-181. 
that is, communism. ${ }^{87}$ But had the twentieth-century left been as bound to linear temporality as these end-of-the-century offers to free us from it seemed to suggest? Certainly most liberals remain as wedded today as they were in the nineteenth century to gradual, patient progress toward "a more perfect [national] union." Yet thinkers on the left have long characterized history not as linear progress but rather as inexorable repetition-of injustice, of oppression, of exploitation. That repetition was what made "Our Dumb Century," as the Onion aptly characterized the twentieth century, so very dumb. ${ }^{88}$ Certainly the linear temporality of national liberal historians offered one way to imagine - and only to imagine-breaking repetition. But liberal temporality became a less and less plausible alternative to the repetition of injustice and oppression as liberalism itself became a global hegemon, with its gruesome excesses from the Paris June Days of 1848 to the so-called War on Terror today.

Marx and Engels, for example, begin the Communist Manifesto, with its otherwise linear temporality, with a reminder that it is repetition, not linear progression, that rules history: "The history of all hitherto existing society is the history of class struggles." (After 1848, Marx and Engels would largely abandon the linear temporality of this very early work. $)^{89}$ Freud, contemplating the trauma of the First World War, similarly marveled at the compulsion to repeat traumatic experiences unconnected to any source of pleasure, leaving him to wonder at the possibility of higher human development. Freud, no revolutionary, resolved this problem as best he could in his 1920 Beyond the Pleasure Principle. ${ }^{90}$ Others have since followed Freud, as well as Marx, in thinking of repetition as a political problem. ${ }^{91}$ Perhaps the greatest left critic of linear temporality was Walter Benjamin, who, in his theses on the philosophy of history, excoriated revisionist Social Democrats for their complacent faith in inevitable progress, and called, in sympathy with the Communist Party of Germany, for revolution. ${ }^{92}$

The discipline of history shares-or at least should share-with popular politics a problem with temporality: how to conceptualize social and political change, how to disrupt repetition, without proposing as a false alternative a linear conception of history that is equally on the side of power, finally part of the repetition characteristic of the

${ }^{87}$ Michel Foucault makes this point in many places, and with special clarity in "Afterword: The Subject and Power," in Hubert L. Dreyfus and Paul Rabinow, Michel Foucault: Beyond Structuralism and Hermeneutics (Chicago, 1982), 208-226; Jean-François Lyotard, The Postmodern Condition: A Report on Knowledge, trans. Geoff Bennington and Brian Massumi (Minneapolis, 1984); Francis Fukuyama, The End of History and the Last Man (New York, 1992).

88 The Onion Presents Our Dumb Century: 100 Years of Headlines from America's Finest News Source, ed. Scott Dikkers (New York, 1999); Lyotard, The Postmodern Condition.

${ }^{89}$ Marx and Engels, Manifesto of the Communist Party (1848), available online at https://www.marx ists.org/archive/marx/works/download/pdf/Manifesto.pdf. See, above all, the opening pages of Marx, The Eighteenth Brumaire of Louis Bonaparte (1852), available online at https://www.marxists.org/archive/marx/ works/download/pdf/18th-Brumaire.pdf. More broadly, see Kevin B. Anderson, Marx at the Margins: On Nationalism, Ethnicity, and Non-Western Societies (Chicago, 2010).

${ }^{90}$ Freud, Beyond the Pleasure Principle (1920), vol. 18 of the Standard Edition of the Complete Psychological Works of Sigmund Freud (London, 1959).

${ }^{91}$ See, for example, Slavoj Žižek, Repeating Lenin (Zagreb, 2001), available online at http://www. lacan.com/replenin.htm; and Alain Badiou, Being and Event, trans. Oliver Feltham (London, 2005; original French ed. 1988).

${ }_{92}$ Walter Benjamin, "On the Concept of History," in Selected Writings, vol. 4: 1938-1940, ed. Howard Eiland and Michael William Jennings, trans. Edmund Jephcott et al. (Cambridge, Mass., 2003), 389400. This was translated earlier as "Theses on the Philosophy of History," in Illuminations, ed. Hannah Arendt, trans. Harry Zohn (New York, 1968), 253-264. 
"dumb" century. Black Lives Matter-the movement and the slogan-offers a possibility of repetition against repetition, a dialectical, counterhegemonic repetition. As a slogan, "Black Lives Matter" seems only to repeat the obvious rather than articulating a demand for the future. But in repeating the obvious as a demand, it highlights the ways that power will not or cannot recognize this obvious fact.

The statement "Black Lives Matter" is thus repetition as dialectical negation. The hapless retort "all lives matter" seeks simply to return this dialectic to an abstract notion basic to liberalism. Attempts to force this dialectic into the linear temporality of dialogue and reform are equally committed to the status quo. In fact, not just recent U.S. history but "the history of all hitherto existing society" in much of the world has repeated again and again its opposite, that black lives - and indeed the lives of any group not defined as "white"do not matter to ruling elites. I am reminded of the brilliant portrayal of the power of counterhegemonic repetition in the 1998 Dogme group film The Celebration. ${ }^{93}$ I would make a similar point about the slogan "We Are the 99\%" from the Occupy movement.

History shares with such counterhegemonic, dialectical repetition a goal of psychoanalysis, articulated by Freud in Beyond the Pleasure Principle: "to force as much as possible into the channel of memory and to allow as little as possible to emerge as repetition." 94 The trick of historians interested in doing what might be called policy-relevant work for popular politics will be to come up with forms of writing commensurate with not only the content but also the form of Black Lives Matter.

AHR Editor: As I bring this conversation to a close, I must say that I am struck by the degree to which my questions have, quite accidentally, provoked extraordinary flights of theory, from Agamben to Žižek and much in between. Yet I am also thrilled by how this high level of conceptual engagement has been rooted in very deep historiographic and empirical ground. Collectively, I think the historiography invoked, the concrete examples given, and the theoretical models alluded to point to a very old question, and yet one that took on quite new dimensions in the historical context of the century just past: What is politics? The effort of Hannah Arendt, frequently referenced in our exchanges, to come to grips with the Marxist tradition and its historical legacy remains one of the most acute registers in which this question has been posed. ${ }^{95}$ For her part, Arendt tended to assume that "historical consciousness" and secular notions of time-the idea that "strictly speaking, repetitions cannot occur"- - accompanied one another. ${ }^{96}$ But our discussion leaves me wondering how we can grasp an epoch which, in Jonathan's apt words, has "generated a crisis in the construction of historical time," whether driven by the exterminatory events of the twentieth century or the looming existential finitude of the present one. And yet I can't help but observe that we-as collective humanity - still have a history, and one that still needs to be reckoned with, even if only in a Sisyphean effort to overcome the past by substituting memory for compulsive repetition. My one regret is that our conversation only rarely touched on that key constituent element in reconceptualizing the recent past: how it is shaped by the Films).

${ }^{93}$ The Celebration, dir. Thomas Vinterberg (Denmark, 1998; distributed in the U.S. by October

${ }^{94}$ Freud, Beyond the Pleasure Principle, 19.

${ }^{95}$ See Hannah Arendt, The Promise of Politics, ed. Jerome Kuhn (New York, 2005).

96 Hannah Arendt, "The Concept of History: Ancient and Modern," in The Portable Hannah Arendt, ed. Peter Baehr (New York, 2003), 278-310, here 297-300, quote from 299. 
disruptive, dynamic, contested process of memory. Raphael Samuel, in his classic Theatres of Memory, observed that professional historians' imposition of historical narrative reduced the past to a "dream-thought," "producing images far clearer than any reality could be." ${ }^{97}$ Such repression and displacement, he maintained, could only be overcome through an appeal to "unofficial history" and practices of popular memory in all its myriad forms. Perhaps this is a conversation to be revisited at the AHA Meeting in Denver in January 2017.

${ }^{97}$ Raphael Samuel, Theatres of Memory: Past and Present in Contemporary Culture, revised paperback ed. (London, 2012), xxiii.

Manu Goswami is Associate Professor of History at New York University. She is the author of Producing India: From Colonial Economy to National Space (University of Chicago Press, 2004). She is currently finishing a book on the political and economic futures envisioned by a variety of twentieth-century internationalisms. Along with Mrinalini Sinha, she is editing a volume on the political imaginaries of India's twentieth century. She is a former fellow of the School for Social Science, Institute for Advanced Study, Princeton University. In 2017-2018, she will be a fellow at the Wissenschaftskolleg zu Berlin, working on a project about the co-evolution of the British Empire and classical and neoclassical economic doctrines and methods. She serves on the editorial boards of Critical Historical Studies, Public Culture, and the American Historical Review.

Gabrielle Hecht is Professor of History at the University of Michigan, where she has also directed the Program in Science, Technology, and Society and served as Associate Director of the African Studies Center. She is the author of two awardwinning books-Being Nuclear: Africans and the Global Uranium Trade (MIT Press, 2012; French edition, Seuil, 2016) and The Radiance of France: Nuclear Power and National Identity after World War II (MIT Press, 1998 and 2009; French editions, La Découverte, 2004 and 2014)—and editor of Entangled Geographies: Empire and Technopolitics in the Global Cold War (MIT Press, 2011). Hecht earned a bachelor's degree in Physics from MIT and a Ph.D. in History and Sociology of Science from the University of Pennsylvania. She has held visiting positions in Australia, France, the Netherlands, Norway, South Africa, and Sweden. She is currently working on two books: an essay collection, Toxic Tales from the African Anthropocene, and a pedagogical survey on Technology and Power in Africa (under contract with Cambridge University Press).

Adeeb Khalid is Jane and Raphael Bernstein Professor of Asian Studies and History at Carleton College in Northfield, Minnesota, where he has taught since 1993. He works on Central Asia in the period after the Russian conquest of the nineteenth century, with thematic interests in religion and cultural change, nationalism, empires, and colonialism. The centrality of Central Asia brings a transnational dimension to his work and puts him in conversation with work on Soviet as well as Middle East history. He has received fellowships from the Guggenheim Foundation, the Carnegie Corporation, and the John W. Kluge Center at the Library of Congress. He is the author of The Politics of Muslim Cultural Reform: Jadidism in Central Asia (University of California Press, 1998), Islam after Communism: Religion and Politics in Central Asia (University of California Press, 2007), and Making Uzbekistan: Nation, Empire, and Revolution in the Early USSR 
(Cornell University Press, 2015). He is currently working on a general history of Central Asia in the modern age.

Anna Krylova is Associate Professor of Modern Russian History at Duke University. She works on twentieth-century Russia and the challenges posed in envisioning and building a socialist alternative in the age of industrial and postindustrial modernity and globalization. Questions of historical theory and gender theory propel her work on contemporary historiography. She is the author of Soviet Women in Combat: A History of Violence on the Eastern Front (Cambridge University Press, 2010), which was awarded the 2011 Herbert Baxter Adams Prize of the American Historical Association. Her second book project, provisionally titled Imagining Socialism in the Soviet Century, aims to make possible a new cultural history of Soviet Russia by historicizing the ways in which normative conceptions of socialist society, sociality, and individuality evolved in Russia from the Revolution of 1905 to Gorbachev's half-decade of perestroika. She is also preparing a historiographical manuscript, The Practice of History in the TwentyFirst Century, featuring essays assessing what has happened to the practice of history since the theoretical and epistemological turmoil of the 1980s-1990s. Most recently, she is the author of "Gender Binary and the Limits of Poststructuralist Method," Gender and History 28, no. 2 (2016): 307-323. She has been a fellow at the National Humanities Center; George Kennan Member at the Institute for Advanced Study, Princeton, New Jersey; a fellow at the Davis Center for Russian and Eurasian Studies at Harvard University; and a visiting scholar at the Institute for Eastern European History and Area Studies at Eberhard Karls Universität in Tübingen, Germany. Her work has been supported by a Mellon Faculty Book Manuscript Workshop Fellowship, the Social Science Research Council (SSRC), and IREX.

Elizabeth F. Thompson, until recently Professor of History at the University of Virginia, is now Farsi Chair of Islamic Peace at American University in Washington, D.C. She is a scholar of imperialism, citizenship, and social movements, particularly concerned with how leaders of Middle Eastern political movements have sought to avoid political violence in favor of peaceful resolutions of conflict. Her most recent book, Justice Interrupted: The Struggle for Constitutional Government in the Middle East (Harvard University Press, 2013), looks at struggles for justice in the Middle East against the growth of tyranny, inequality, and foreign intervention since the late nineteenth century. It demonstrates that Islamic movements share a history of liberal politics with secular movements. Her first book, Colonial Citizens: Republican Rights, Paternal Privilege, and Gender in French Syria and Lebanon (Columbia University Press, 2000), examined the gendered construction of political space and the consequent distancing of female citizens from direct access to the state. It won two national history prizes. With support from the Carnegie Corporation and the Woodrow Wilson International Center for Scholars, Thompson is currently working on a third book, After Lawrence: Woodrow Wilson and the Promise of Islamic Democracy in Syria.

Jonathan R. Zatlin is Associate Professor of History at Boston University and Associate Director of the Arvind and Chandan Nandlal Kilachand Honors College. Along with his colleagues Andrew Bacevich, Brooke Blower, and Bruce Schulman, he organized the Mellon Foundation Sawyer Seminar Series in 2014/ 2015 around the topic "Reinterpreting the Twentieth Century." He has written widely on the history of German communism, from Marxist economic theory, economic planning, socialist consumer policy, the East German automobile industry, and the socialist production and consumption of women's lingerie to pop- 
ular opinion under communism, the East German secret police, racism in Sovietstyle regimes, and the politics of German unification. He is the author of The Currency of Socialism: Money and Political Culture in East Germany (Cambridge University Press, 2007), and co-editor, with Pamela E. Swett and S. Jonathan Wiesen, of Selling Modernity: Advertising in Twentieth-Century Germany (Duke University Press, 2007). His current research investigates the link between race and economy in modern European history, focusing on the experience of German Jews. Together with Christoph Kreutzmüller, he is co-editor of Dispossession: Plundering German Jewry, 1933-1945 (under contract at University of Michigan Press) and is currently working on a monograph titled Fantasies of Jewish Wealth in Germany, 1870-1990.

Andrew Zimmerman is Professor of History at the George Washington University. His research focuses on empires and revolutions in Europe, the United States, and West Africa and seeks to create dialogues between theory, especially Marxism and psychoanalysis, and transnational archival research. He is the author of Anthropology and Antihumanism in Imperial Germany (University of Chicago Press, 2001) and Alabama in Africa: Booker T. Washington, the German Empire, and the Globalization of the New South (Princeton University Press, 2010). He has also edited Karl Marx and Friedrich Engels, The Civil War in the United States (International Publishers, 2016). He is currently writing a history of the American Civil War as a transnational revolution against slave labor and wage labor. His next project will be an intellectual history of rural insurgency from the global French Revolution to global Maoism. 